\title{
PROBLEMATIC GROUPS OF BRACHYTHECIUM AND EURHYNCHIASTRUM (BRACHYTHECIACEAE, BRYOPHYTA) AND TAXONOMIC SOLUTIONS SUGGESTED BY nrITS SEQUENCES
}

\author{
ПРОБЛЕМНЫЕ ГРУППЫ РОДОВ ВRАСНYТНЕСIUМ И ЕURHYNCHIASTRUM \\ (BRACHYTHECIACEAE, ВRYOРНYТА) И ВОЗМОЖНЫЕ \\ ТАХОНОМИЧЕСКИЕ РЕШЕНИЯ НА ОСНОВЕ ПОСЛЕДОВАТЕЛЬНОСТЕЙ
}

\author{
M.S. IGNATOV ${ }^{1}$, I.A. MiLYUTINA ${ }^{2} \&$ V.K. BOBROVA ${ }^{2}$ \\ М.С. ИГНАТОВ ${ }^{1}$, И.А. МИЛЮТИНА ${ }^{2}$, В.К. БОБРОВА ${ }^{2}$
}

Abstract

The revision of Brachythecium from Russia that use both traditional morphological appoach in combination with nuclear ITS study reveals three undescribed species in Asian part of the country. They are described here as $B$. baicalense, $B$. boreale, and $B$. extremiorientale. The species status of $B$. udum, $B$. acutum, $B$. brandegei, $B$. rotaeanum is discussed. Brachythecium digastrum is synonymized with $B$. laetum. New combinations: Eurhynchiastrum pulchellum var. barnesii and Sciuro-hypnum delicatulum are suggested. Brachythecium buchananii is revealed in Europe. ITS data allow to reduce the ambiguity of taxonomic decisions in the group, although sometimes good species has no difference in ITS between species, e.g. in group of $B$. salebrosum $+B$. erythrorrhizon + B.brandegei + B.glareosum .

Резюме

Изучение рода Brachythecium с помощью классических морфологических методов при использовании данных по нуклеотидным последовательностям ядерных ITS позволило выявить три новых для науки вида, которые и описываются в статье: B. baicalense, B. boreale, B. extremiorientale. Обсуждается также видовая самостоятельность B. udum, B. acutum, B. brandegei, B. rotaeanum. Brachythecium digastrum отнесен в синонимы к B. laetum. Предложены новые комбинации: Eurhynchiastrum pulchellum var. barnesii и Sciuro-hypnum delicatulum. Brachythecium buchananii впервые выявлен для Европы. Изучение последовательностей ITS позволяет существенно уменьшить уровень неопределенности таксономических решений. Вместе с тем, некоторые группы, например $B$. salebrosum $+B$. erythrorrhizon + B.brandegei+B.glareosum не имеют отличий в ITS.

KEYWORDS: mosses, Brachythecium, Brachytheciaceae, taxonomy, ITS, molecular phylogenetics, Russia, North America

INTRODUCTION

Brachythecium is one of the largest genera in the Northern Hemisphere and its species are often considered quite difficult to identify. Morphological variation within species is high, diagnostic characters are not constantly persent, and al- though taxonomic treatments from different parts of the world use the same names, they circumscribe the taxa in different ways.

The revision of the genus in Russia has faced many difficulties. In many cases, our attempts at species identification, especially from Asia, re-

1 - Main Botanical Garden of Russian Academy of Sciences, Botanicheskaya, 4, Moscow 127276 Russia - Россия 27276 Москва, Ботаническая, 4, Главный ботанический сад им. Н.В.Цицина PAH; misha_ignatov@list ru

2 - A.N.Belozersky' Research Institute of Physico-Chemical Biology, Moscow State University, Moscow 119991 Russia - НИИ Физико-химической биологии им. А.Н. Белозерского, МГУ, Москва 119991 
mained 'hanging', as European, Japanese, Chinese and North American treatments did not provide satisfactory solutions. In the course of the work on the moss flora of North America, additional problems have appeared as no correlation of names has been undertaken between these continents in recent decades.

In addition to morphological studies, we also studied nr ITS sequences, as they have proved to be powerful tools for taxonomic elucidation at various levels, including for species (Fedosov \& Ignatova, 2008; Goryunov et al., 2007; Ignatova \& Fedosov, 2008, etc.). However, the family Brachytheciaceae is not easy in this regard because ITS variation within genera is very low (e.g. Ignatov \& Milyutina, 2007). Nevertheless, unique substitutions in combination with the use of morphological characters allows a better delimitation of at least some taxa. Many problems remain and their solution will need additional fieldwork and sampling, so only a preliminary analysis is possible now. However, this analysis solves a few problems, supports some nomenclatural suggestions, and indicates especially poorly understood groups that need further investigation.

\section{MATERIAL AND METHODS}

Since a preliminary phylogenetic study has been completed for Brachythecium (Huttunen \& Ignatov, 2004; Huttunen et al., 2007), we here attempt here to test affinities of 'untypical' specimens (i.e., where morphology admits quite alternative interpretations) using ITS data. Selection of material was made in the course of identification of collections from different parts of the circumboreal zone in the Northern Hemisphere, especially from Russia. After a certain amount of data had been accumulated and outlines of some previously unrecognized groups appeared, additional sampling of specimens morphologically similar to the latter was undertaken. Another aim of the work was to check the identity of Eurasian and North American plants traditionally referred to the same or related species.

As some specimens studied for DNA long ago have only ITS1 or only ITS2 data, two analyses were performed: a smaller dataset included 51 specimens of Brachythecium that have both ITS1 and ITS2 data, while a larger dataset was supplemented by 13 additional specimens that have either ITS1, or ITS2 data.
The protocol of DNA extraction, PCR and sequencing of ITS data was the same as described by Gardiner et al. (2005). Sequences were aligned manually in Bioedit (Hall, 1999). Parsimony analysis was completed with Nona (Goloboff, 1994) within the Winclada shell (Nixon, 1999a). A multiratchet option with five sequential parsimony ratchet runs was employed (Nixon, 1999b). Jackknifing with 1000 replications was performed with Nona within the Winclada shell.

Type material of some studied taxa is commented when necessary, and in a few cases we discuss the taxonomy of species that were not sequenced due to lack of fresh material.

\section{RESULTS}

Sequence variation of is rather low and some species have no single molecular synapomorphy. The jackknife values in the analysis of the larger dataset were rather high, 85 , only for a clade formed by B. frigidum, B. asperifolium and B. baicalense, and moderately high, 74 , for a clade formed by four specimens of the here newly described here $B$. boreale. A strict consensus tree (not shown) received very poor resolution, and the $50 \%$ majority tree (Fig. 1) has many clades that are not resolved in the strict consensus. However, many of these poorly supported clades join specimens of morphologically circumscribed species, and are therefore worth of discussing.

The analysis of the smaller dataset results in a very similar topology, and as this dataset did not include incomplete data, the support of many clades raises. The main polytomy includes (1) Brachythecium auriculatum; (2) B. campestre; (3) The B. rivulare-rutabulum-frigidum-group; (4) A clade that includes species of the B. salebrosum-group, the B. buchananii-group, and species around $B$. laetum and B. mildeanum. The latter clade \#4 received a high support, 99. The high support was found mostly for individual species, and for pairs: B. rivulare-B. rutabulum (99), $B$. asperrimum-B. frigidum (96), B. asperrimum $-B$. frigidum-B. baicalense (84), B. campestre-B. complanatum (98), B. mildeanum-B. acutum (98); the whole $B$. buchananii-group got a almost no support of 66, as well as clade of $B$. rotaeanum 57 , but two specimens of $B$. rotaeanum, from SE Europe and eastern North America, form a smaller clade with support of 76 . 


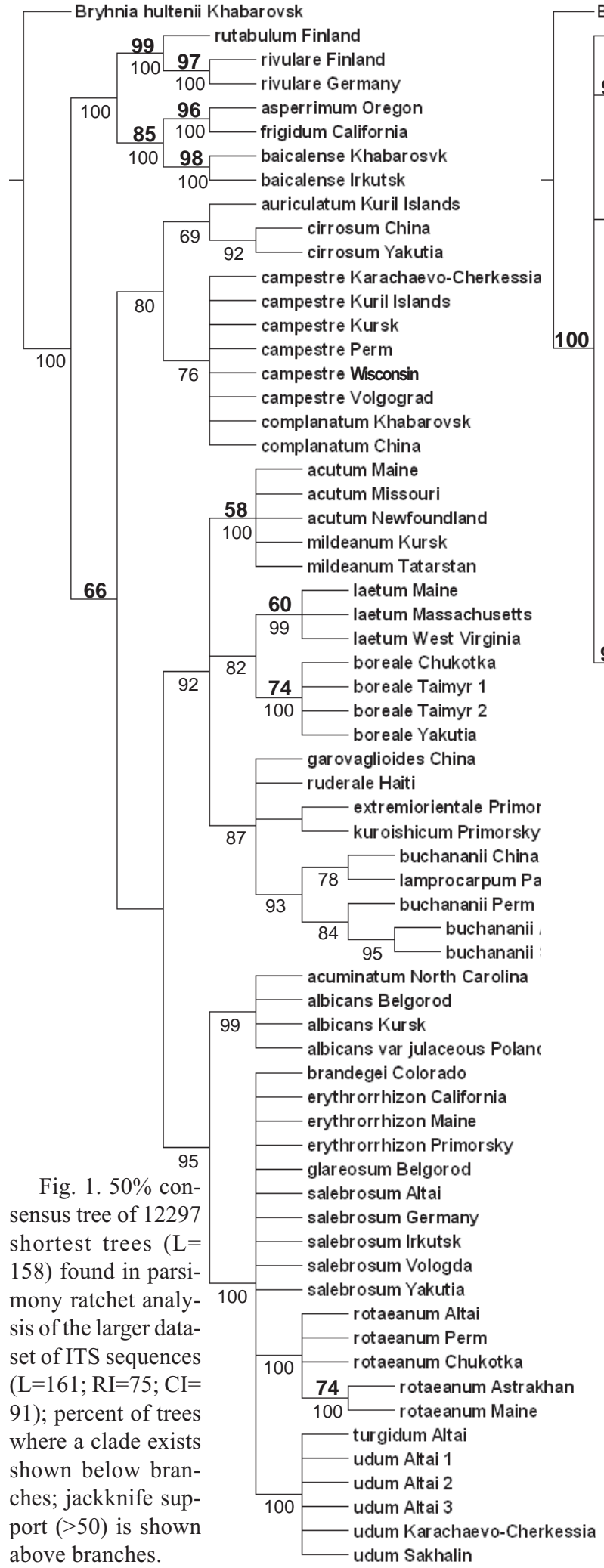

Bryhnia hultenii Khabarovsk
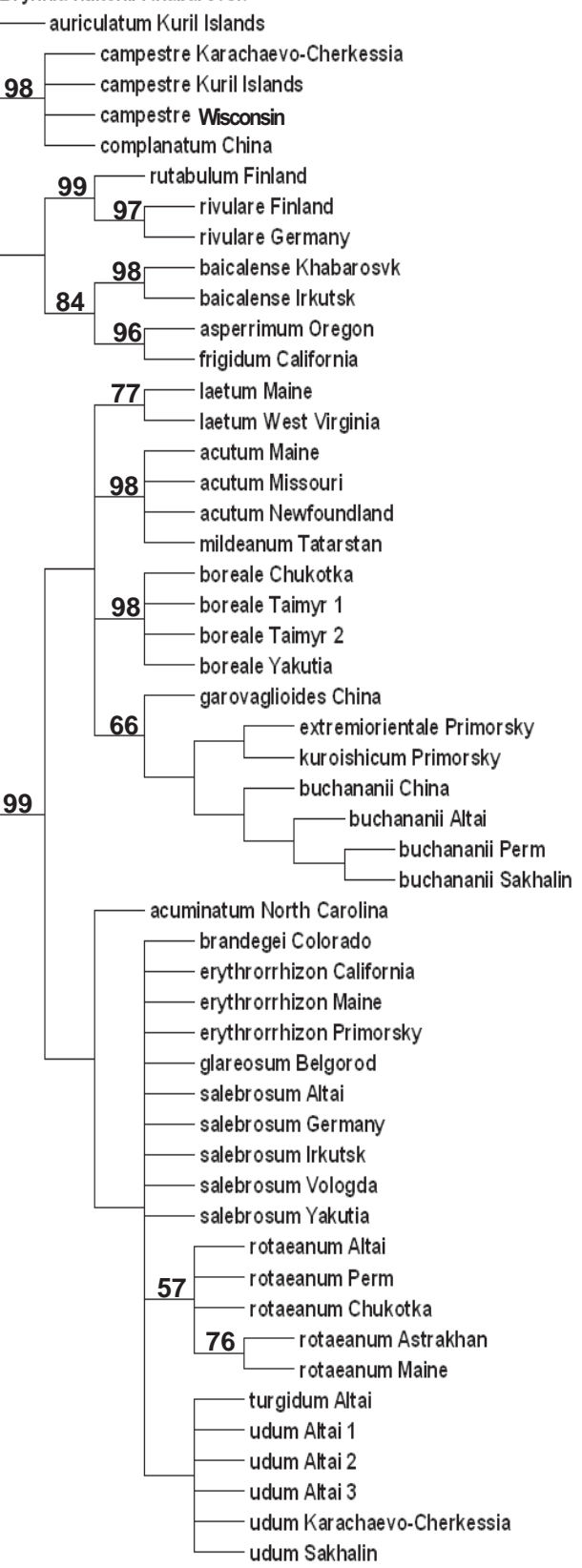

Fig. 2. Strict consensus tree of 221 shortest trees $(\mathrm{L}=149)$ found in parsimony ratchet analysis of the smaller dataset of ITS sequences $\quad(\mathrm{L}=154 ; \mathrm{RI}=79 ; \mathrm{CI}=93)$; jackknife support $(>50)$ is shown above branches. Data on specimens are given in Table 1. 
Table 1. Data on specimens used in phylogenetic analysis.

\section{Brachytheciastrum}

\section{collinum}

(Müll. Hal.) Ignatov \& Huttunen EF617553 EF617553 Russia, Astrakhan Prov., Suragina 5.V.2002 (MHA)

\section{Brachythecium}

B. acuminatum (Hedw.) Austin

B. acutum (Mitt.) Sull.

B. acutum

B. acutum

GQ246810 AF403654 U.S.A., North Carolina, Anderson 24257 (H)

GQ246821 GQ246821 U.S.A., Maine, Allen 28201 (MO)

GQ246822 GQ246822 U.S.A., Missouri, Allen 26741 (MO)

GQ246823 GQ246823 Canada, Newfoundland, Buck 52529 (NY)

B. albicans (Hedw.) Bruch et al.

B. albicans

GQ246811 -

GQ246812 -

B. albicans var. julaceum Warnst. GQ246813 -

B. asperrimum

(Mitt. ex Müll.Hal.) Sull.

B. auriculatum A.Jaeger

B. baicalense Ignatov

\section{B. baicalense}

B. boreale Ignatov

$B$. boreale

B. boreale Taimyr 1

B. boreale Taimyr 2

B. brandegei (Austin) H.Rob.

B. buchananii (Hook.) Jaeger

B. buchananii

B. buchananii

B. buchananii

B. cirrosum (Schwaegr.) Schimp.

B. cirrosum

B. campestre

(Müll. Hal.) Bruch et al.

B. campestre

B. campestre

B. campestre

B. campestre

B. campestre

B. complanatum Broth.

B. complanatum

B. erythrorhizon Bruch et al.

B. erythrorhizon

B. erythrorhizon

B. erythrorhizon

$B$. extremiorientale Ignatov

B. frigidum (Müll. Hal.) Besch.

B. garovaglioides Müll. Hal.

B. glareosum

(Bruch ex Spruce) Bruch et al.

B. kuroishicum Besch.

B. laetum (Brid.) Bruch et al. GQ246818 -
Russia, Belgorod Prov., Ignatov 13.V.1999 (MHA)

Russia, Kursk Prov., Ignatov 20.V.1999 (MHA)

Poland, Ochyra 13.IV.1987 (MHA)

GQ246824 GQ246824 U.S.A., Oregon, Darigo 3977 (MO)

DQ497446 DQ497446 Russia, Kuril Is., Bardunov 10.IX.1980 (MHA ex IRK)

GQ246825 GQ246825 Russia, Khabarovsk Territory, Bureya, Ignatov 97-1115 (MHA)

GQ246826 GQ246826 Russia, Irkutsk Prov., Slyudyanka, Ignatov \& Kazanovsky 05-6010 (MHA)

GQ246827 GQ246827 Russia, Chukotka, Afonina 20.VIII.2001 (MHAex LE)

GQ246828 GQ246828 Russia, Yakutia, Ignatov 00-1074 (MHA)

GQ246829 GQ246829 Russia, Taimyr, Fedosov, 05-31 (MW)

GQ246830 GQ246830 Russia, Taimyr, Fedosov 05-650 (MW)

GQ246831 GQ246831 U.S.A., Colorado, Weber B-114286 (MHA ex COLO)

GQ246832 GQ246832 Russia, Perm Prov., Bezgodov N176 11.VIII.2005(MHA)

DQ200075 AF403595 China, Koponen et al. $53972(\mathrm{H})$

GQ246833 GQ246833 Russia, Altai, Ignatov 29/29 (MHA)

GQ246834 GQ246834 Russia, Sakhalin, Ignatov 06-196 (MHA)

- $\quad$ AF403641 China, Xianjing, Tan 93-846(H)

AF403641 Russia, Yakutia, Ignatov 00-26 (H ex MHA)

GQ246814 - Russia, Perm Prov., Bezgodov 682 (MHA)

GQ246835 GQ246835 Russia, Kuril Is., Ignatov 06-1560 (MHA)

GQ246815 - Russia, Kursk Prov., Ignatov 14.VIII.1996 (MHA)

GQ246836 GQ246836 Russia, Karachaevo-Cherkessia, Ignatov \& Ignatova 05-3789 (MW)

GQ246816 - Russia, Volgograd Prov., Ignatov 10.VIII.1999 (MHA)

GQ246837 GQ246837 U.S.A., Wisconsin, Bowers 11-10-1990 (MO)

- $\quad$ AY166444 Russian, Khabarovsk Territory, Bureya, Ignatov 97-172 (MHA)

GQ246838 GQ246838 China, Cao Tong 040063 (MHA)

GQ246817 - Russia, Arkhangelsk, Churakova 1148 (MHA)

GQ246839 GQ246839 U.S.A., Maine, Allen 28225 (MO)

GQ246840 GQ246840 Russia, Primorsky Territory, Ignatov et al. 06-2122 (MHA)

GQ246841 GQ246841 U.S.A., California, Ignatov 27-8-1989 (MHA)

GQ246842 GQ246842 Russia, Primorsky Territory, Ignatov \& Ignatova 06-2935 (MHA)

DQ336898 AF403638 USA, California, Düll, 23.IV.1981 (H)

DQ497445 DQ497445 China, Fuan 960785 (PE ex MHA)

GQ246843 GQ246843 Russia, Belgorod Prov., Ignatov14.V.1999 (MHA)

DQ497444 DQ497444 Russia, Primorsky Territory, Cherdantseva 15.IV.1991

(MHA ex VLAD)

U.S.A., Massachusetts, Tan 91-501 (MHA) 
B. laetum (morphotype 'digastrum') GQ246844 GQ246844 U.S.A., West Virginia, Buck 36983 (NY)

B. laetum

GQ246845 GQ246845 U.S.A., Maine, Allen 28393 (MO)

B. lampocarpum (Müll.Hal.) A.Jaeger -

AF403584 Papua New Guinea, Koponen 28748 (H)

B. mildeanum (Schimp.) Schimp.

AY166441 Russia, Kursk Prov., Ignatov 20.V.1999 (MHA)

B. mildeanum

B. rivulare Bruch et al.

GQ246846 GQ246846 Russia, Tatarstan, Ignatov \& Ignatova 18.VIII.2003(MHA)

B. rivulare

DQ200076 AF403651 Finland, Parnela 19.V.1996 (H)

B. rotaeanum De Not.

DQ200077 DQ200077 Germany, Frahm 19.VI.1999 (BONN)

B. rotaeanum

GQ246847 GQ246847 Russia, Chukotka, Afonina 24.VIII.2001 (MHA ex LE)

B. rotaeanum

GQ246848 GQ246848 Russia, Astrakhan Prov., Suragina 5.V.2002 (MHA)

B. rotaeanum

GQ246849 GQ246849 Russia, Altai, Ignatov 0/3004 (MHA)

B. rotaeanum

B. ruderale (Brid.) Buck

GQ246850 GQ246850 Russia, Perm Prov., Bezgodov 20.IX.2003 \#65 (MHA)

GQ246851 GQ246851 U.S.A., Maine, Allen 28536 (MO)

B. rutabulum (Hedw.) Bruch et al. DQ200078 AF403644 Finland, Huttunen 1415 (H)

B. salebrosum

(F. Web. \& D. Mohr) Bruch et al.

B. salebrosum

B. salebrosum

B. salebrosum

B. salebrosum

B. salebrosum

B. turgidum (Hartm.) Kindb.

B. udum I. Hag. Altai 1

B. udum Altai 2

B. udum Altai 3

B. udum

GQ246852 GQ246852 Russia, Irkutsk Prov., Ignatov 8.VI.2005 (MHA)

GQ246819 - Russia, Bashkortostan, Zolotov 08-6 (MHA)

GQ246853 GQ246853 Russia, Altai, Ignatov 14/61 (MHA)

GQ246854 GQ246854 Russia, Vologda Prov., Ignatov \&

Ignatova 12.VIII.2001 (MHA)

GQ246855 GQ246855 Russia, Yakutia, Ignatov 00-866 (MHA)

AY654609 AY654609 Germany, Goffinet 4723

GQ246856 GQ246856 Russia, Altai, Ignatov 31/291 (MHA)

GQ246857 GQ246857 Russia, Altai, Ignatov 0/444 (MHA)

GQ246858 GQ246858 Russia, Altai, Ignatov 15/112 (MHA)

GQ246859 GQ246859 Russia, Altai, Ignatov 31/297 (MHA)

B. udum

GQ246860 GQ246860 Russia, Karachaevo-Cherkessia, Ignatova 07-156(MW)

GQ246861 GQ246861 Russia, Sakhalin, Ignatov\& Teleganova21.VIII.2006(MHA)

\section{Bryhnia}

hultenii E.D.Bartram

GQ246820 GQ246820 Russia, Khabarovsk Territory, Bureya

Ignatov 97-1282 (MHA)

\section{Eurhynchiastrum}

pulchellum (Hedw.)

Ignatov \& Huttunen France 1

pulchellum France2

pulchellum

pulchellum

pulchellum

pulchellum var. barnesii

(Renauld \& Cardot) Ignatov GQ254299 GQ254299 Canada, British Columbia, Schofield 85054 (UBCU)

AY737470 AY737470 France, Sotiaux 14737

AY737465 AY737465 France, Sotiaux 13234

AY737468 AY737468 Italy, Blockeel 26/519

FM161101 FM161101 Finland, Koponen \& Huttunen $1321(\mathrm{H})$

GQ254298 GQ254298 Canada, British Columbia, Vitt 35808a

[admixture to 35808] (MHA)

\section{DISCUSSION}

The overall topology of the phylogenetic tree obtained in the present study is similar to previous results (e.g. Ignatov \& Huttunen, 2002; Huttunen \& Ignatov, 2004; Huttunen et al., 2007, etc.). The group of hygrophilous species around $B$. rivulare with rough setae is basal, whereas the group with smooth setae (usually named as sect. Salebrosa) is in a terminal position. The $B$. salebrosum group was not resolved in the present analysis as ITS has no synapomorphies for the salebrosum-erythror- rhizon-glareosum-brandegei-complex. Only a few contrastingly different species in this group are commented on here.

At the same time, some species, e.g. B. rotaeanum and $B$. udum differ from 'average $B$. salebrosum' in only one or two substitutions, but they are consistently present in all of the studied specimens and consistently agree with morphology. This fact forces us to analyze even singular substitutions.

In several cases, the positions of 'enigmatic specimens' were resolved by molecular data, en- 


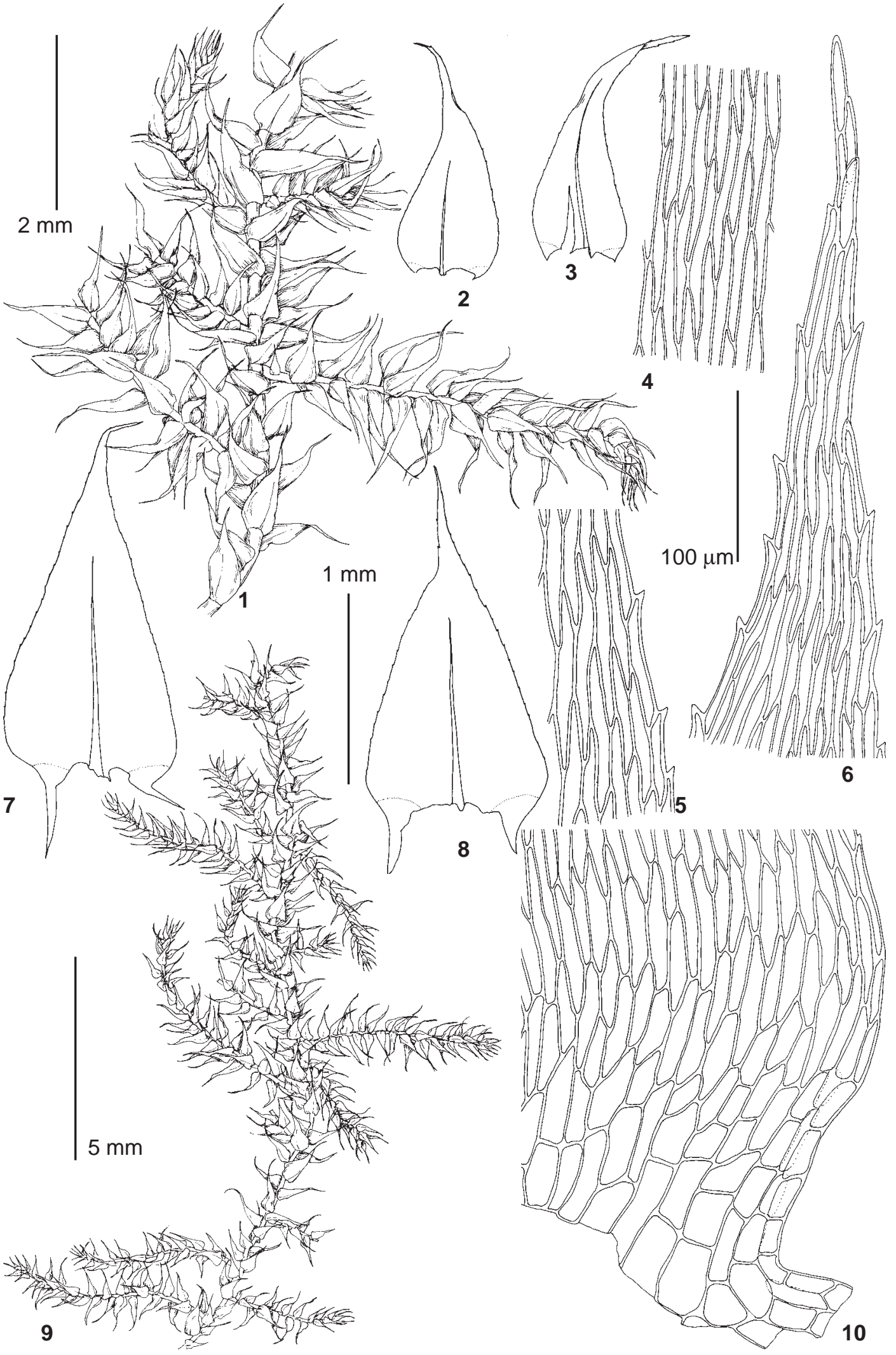


couraging the description of new species, especially when they aer clearly distinct from species resolved as their closest relatives.

1. Brachythecium baicalense Ignatov sp. nov. Figs. 3, 9 .

Species haec habitu, ITS sequentia, foliis ovato-lanceolatis vel lanceolatis, margine serratis, cellulis laminae angustis et cellulis alaribus paucis, hyalinis inflatisque Brachythecio asperrimo similis, sed inflorescentiis monoicis et setis glabris differt.

Typus: Siberia, Irkutsk Prov., Slyudyanka Distr., Slyudyanka Creek $7 \mathrm{~km}$ upstream from mouth, $51^{\circ} 37.5^{\prime} \mathrm{N}-103^{\circ} 39^{\prime} \mathrm{E}, 650 \mathrm{~m}$ alt., on rotten $\log$ in valley, 8.VI.2005, M. Ignatov \& S. Kazanovsky 05-6010 (holotypus MHA).

Plants medium-sized, in loose tufts, light green to yellowish or whitish green. Stems to $5 \mathrm{~cm}$, prostrate to arching, terete foliate, irregularly to regularly pinnately branched; branches often deviating from stem with at about a right angle, to $5 \mathrm{~mm}$, straight to slightly curved, terete foliate. Stem leaves erecto-patent to patent, $1.8-2.2 \times 0.8-1.1 \mathrm{~mm}$, ovatetriangular (broadest at about 1/10 of leaf length), gradually tapered to apex, and short or moderately long acuminate, rounded to insertion, conspicuously decurrent, not or weakly plicate; margins plane, serrate to strongly so; costa slender, reaching 0.60.75 of leaf length, ending in a small spine or not; laminal cells $70-120 \times 5-8 \mu \mathrm{m}$; narrow almost to leaf base, cells to leaf corners enlarged, forming indistinctly delimited pellucid group. Branch leaves smaller to strongly and abruptly smaller, more strongly serrate. Sexual condition autoicous. Seta 15-20 mm, smooth. Capsule inclined to horizontal, somewhat curved, ca. $20 \mathrm{~mm}$ long, operculum unknown. Spores 15-17 $\mu \mathrm{m}$.

Brachythecium baicalense forms a clade sister to North American B. frigidum and B. asperrimum. Brachythecium frigidum is very common in Pacific North-West of North America and was recently collected in Russian Far East (Bakalin, VLA, MHA). It is a highly variable species, but is usually easy to identify due to many characters that are otherwise rare in the genus: the leaves are rigid, strongly plicate, conspicously triangular (i.e., leaf margins are tapering to apex in straight lines), the marginal cells are short and form sharp serrations, the alar region is somewhat auriculate, the alar cells are large, and cells in one row across the whole base at insertion are conspicuously enlarged.

The sister species to B. frigidum is B. asperrimum, a species that was synonymized with $B$. frigidum in the Canadian check-list (Ireland et al., 1987), but considered a species in the North American checklist (Anderson et al., 1990). This synonymization was apparently based on assumption that B. asperrimum is a poorly developed B. frigidum. Brachythecium asperrimum is one of the most variable species in North America; it has been described under six different species names and Grout (1928) accepted three of them as species. It is variable in size from moderately small to rather robust, and forms loose to moderately dense tufts; its stems are creeping to arching, straight to flexuose, terete to subcomplanately foliate; its leaves are densely to very loosely arranged, erect to falcate-secund, ovate to lanceolate; and the leaf margins are distinctly serrate to occasionally subentire. However it can usualy be recognized by remote foliage, narrow leaves, enlarged basal cells, and by almost always having sharply serrate leaf margin.

These characteristics of $B$. asperrimum are provided here to parallel its variation pattern with $B$. baicalense that is gametophytically closest to B. asperrimum, and also exhibits great variation even among a limited number of specimens. Most collections are composed of slender, loosely foliate plants that habitually look like a depressed phenotyte of B. salebrosum. The differences from this species include enlarged alar cells, unusually strong marginal serration, and narrow and long laminal cells, reminiscent of Sciuro-hypnum starkei to which it was referred when collected by one of the authors, MI, for the first time in a sterile state (Ignatov et al., 2000). The important difference between $B$. baicalense and both $B$. frigidum and $B$. asperifolium is the monoicous sexual condition and smooth seta. The latter character and a contrastingly different habit distinguishes B. baicalense from S. starkei.

Fig. 3. Brachythecium baicalense (from holotype: Irkutsk Prov., Ignatov \& Kazanovsky, 05-6010 MHA): 1, 9 - habit (dry); 2-3 - branch leaves; 4-5 - mid-leaf cells; 6 - upper leaf cells; 7-8 - stem leaves; 10 - basal leaf cells. Scale bars: $5 \mathrm{~mm}$ for $9 ; 2 \mathrm{~mm}$ for $1 ; 1 \mathrm{~mm}$ for $2-3,7-8 ; 100 \mu \mathrm{m}$ for 4-6, 10 . 


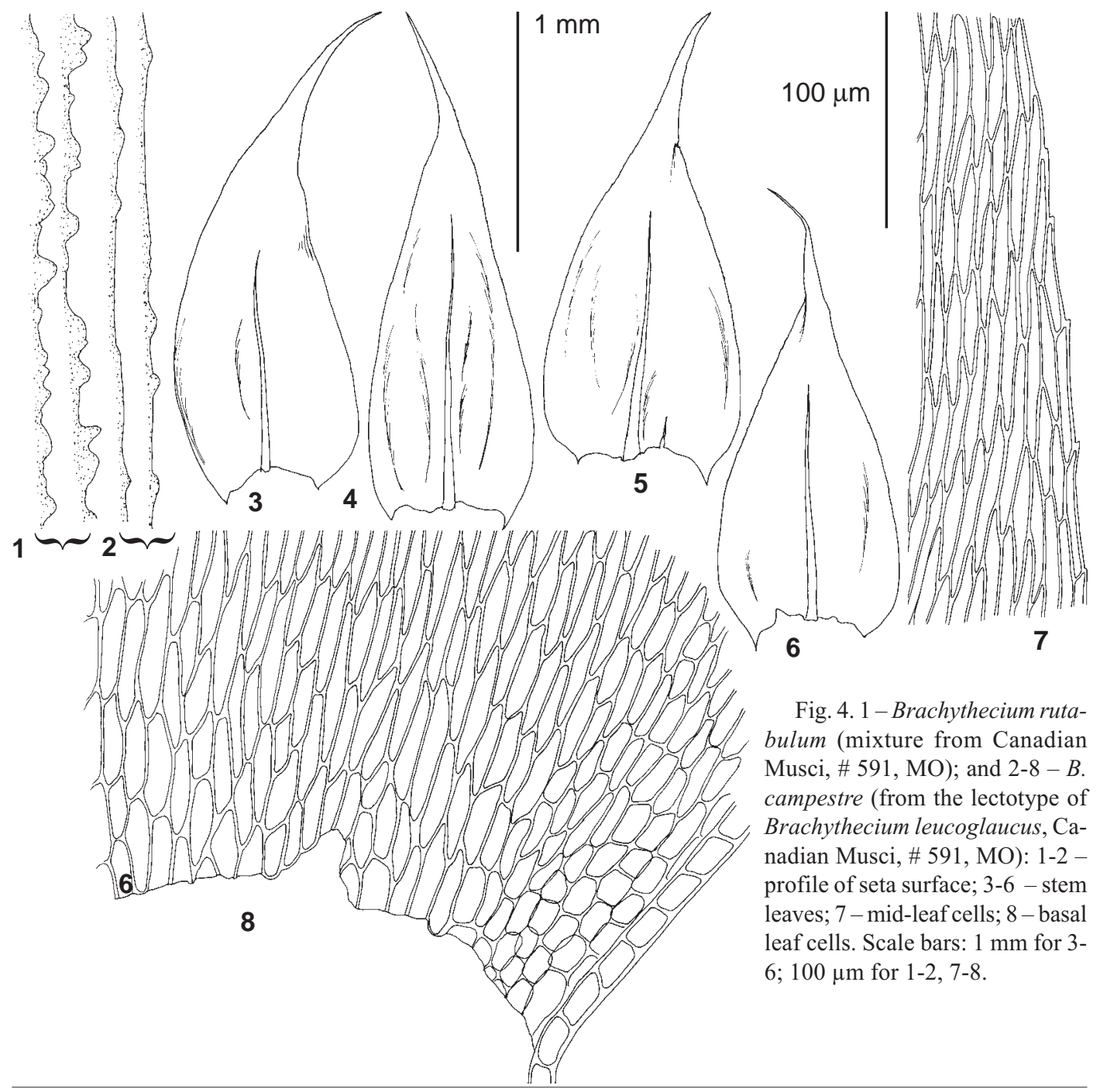

Poor collections of B. baicalense without gametangia are very difficult to differentiate from underdeveloped morphotypes of $B$. salebrosum from shaded habitats where small subquadrate cells in the leaf corners are not always clearly expressed. The comparison with $B$. boreale is given under that species.

Specimens examined: Amurskaya Prov.: Bureya River near Ostashino, year 1909, Fedchenko \#527 (LE); Irkutsk Prov.: Slyudyanka, Ignatov \& Kazanovsky, 05-6010 (MHA); Khabarovsk Territory, Levaya Bureya River, Ignatov 97-1113 (MHA), 97-313 (MHA), 97-310 (MHA); Chegdomyn, Ignatov 97-1115 (MHA); Yakutia (South-West), Vitim River, Ivanova 13.VI.2004 (SASY ex MHA); same 9.VI.2004 (SASY ex MHA).
Most collections of $B$. baicalense are from fallen logs in flood-valleys, at low elevations. In general this seems to be a rare species.

\section{Brachythecium campestre. Fig. 4: 2-8.}

Brachythecium campestre, as many authors have noted, is a very similar species to $B$. salebrosum and it is very difficult to separate them in many cases. Grout (1928) expressed some doubts that B. campestre is a good species and Crum \& Anderson (1981) wrote that it "certainly cannot be considered a species of the first rank". The controversial approaches to circumscription of this species in Europe were discussed by Hedenäs (1995), who considered this species as a close one to B. albicans and B. salebrosum, which is most likely from its morphology. 
However, B. campestre (plus 'B. complanatum', see below) was found to be one of the most distinct species in Brachythecium using molecular data. Some motifs are the same as in B. rutabulum and $B$. rivulare, while other are similar to the $B$. salebrousum-group, and, probably, $B$. campestre $(\mathrm{n}=11,12,16,17)$ can be suspected of hybrid origin, although its morphological similarity with $B$. salebrosum $(\mathrm{n}=10,12,13)$ is more sound than with that of $B$. rivulare (most counts $\mathrm{n}=6$ ). Chromosome data, however, are taken from the literature (Lazarenko et al., 1971; Fritsch, 1991), so combined molecular and karyological study is necessary to confirm or reject this hypothesis.

Even if the hypothesis of hybrid origin is correct, at the moment $B$. campestre is quite stable: plants from the Pacific coast of Asia, Central Asia, Europe, and Eastern North America are subidentical by ITS and also have similar morphologies. The main features differentiating $B$. campestre from B. salebrosum include: 1) leaves are concave and plicate, but the plicae are more or less parallel only in the more narrow and falcate leaves, while the broader, more deeply concave and straight leaves have crumpling surfaces with only shallow plicae in divergent directions; concave leaves make the plant foliage more julaceous, thus, superficially, $B$. campestre is often more like robust $B$. albicans than $B$. salebrosum; 2) cells in the leaf corners are subquadrate or short rectangular, forming a more or less extensive group (larger than in B. salebrosum), or, often, the group is rather small and compact (not larger than in $B$. salebrosum), but in this case it usually has a pellucid zone of supra-alar cells that form a conspicuous group along leaf margin, just above the small leaf corner cells, extending up to the broadest pertion of the leaf, almost forming auricles when well expressed; this pattern seems to correspond to the rather abrupt constriction, or 'rounding' to the leaf base, somewhat resembling that of B. rutabulum. Contrary to this, the leaves of $B$. salebrosum have much less constriction to the base, a smaller and a more distinctly delimited square group of cells in the leaf corners, and its leaves are either clearly longitudinally plicate or rather smooth when it is growing in wet and shady forests; 3 ) the seta of $B$. campestre is rough in most populations.
There are some small differences between European and American populations of B. campestre: American populations have, usually, narrower and more or less falcate leaves, while European plants have often relatively broad leaves that are usually straight, and the seta is usually more conspicuously rough in American plants than European ones where the seta is often almost or even totally smooth or with low mammillae. If future studies provide additional evidence for their separation, the appropriate name for the American 'B. campestre' should be Brachythecium leucoglaucum Müll. Hal. \& Kindb.

Brachythecium leucoglaucum, according to Grout (1928) and subsequent authors, is a synonym of $B$. rutabulum. This decision was apparently accepted because the type collection, the exsiccate \#591 (specimen in MO), contains two plants, one of $B$. rutabulum and other $B$. campestre (Fig. 4). The description itself, as well as the name, refers to the latter one: plants of $B$. rutabulum are bright green (not 'whitish to subglaucous green', as stated in the protologue), have large alar cells (not 'alar cells small'), and have strongly rough seta (not 'faintly rough'). In addition, another exsiccate, of B. leucoglaucus, Canadian Mosses \#297, includes only B. campestre. Thus the lectotype of Brachythecium leucoglaucus is selected here:

Brachythecium leucoglaucum Müll. Hal. \& Kindb. Catalogue of Canadian Plants, Part VI, Musci 198. 1892.

Lectotype, designated here: Canadian Musci, Prepared by J. Macoun, 591. Brachythecium leucoglaucum, C.M. \& Kindb., On loose Earth, Queens Co., N.B. [New Brunsvick] Sept. 10th, 1888, Coll. J. Moser (MO!) [plant in a separate envelope, annotated by M. Ignatov].

Selected North America specimen studied (with the state/province abbreviations of BFNA, specimens in MO, if otherwise not indicated): Man. (Bird 5774), N.B. (Allen 2141), Nfld. (Waghorne 23.???.1891), N.S. (King \& Garvey B623), Ont. (Dupret March 28, 1910), Sask. (GN Jones 43477), Conn. (Pease 456), Del. (Reed 132429), Iowa (Allen 10896), Maine (Allen 22419), Mich. (Flowers 3209 (NY)), Minn. (Churchill 6295), Mo. (Darigo 4026), N.H. (Allen 24582), N.Y. (Allen 7908), R.I. (Allen 20438), S.Dak. (Churchill 11331), Wis. (Bowers 11.X.1990). Specimens from Russia are available from: http://gis-app.ict.nsc.ru/bio/search.php. 


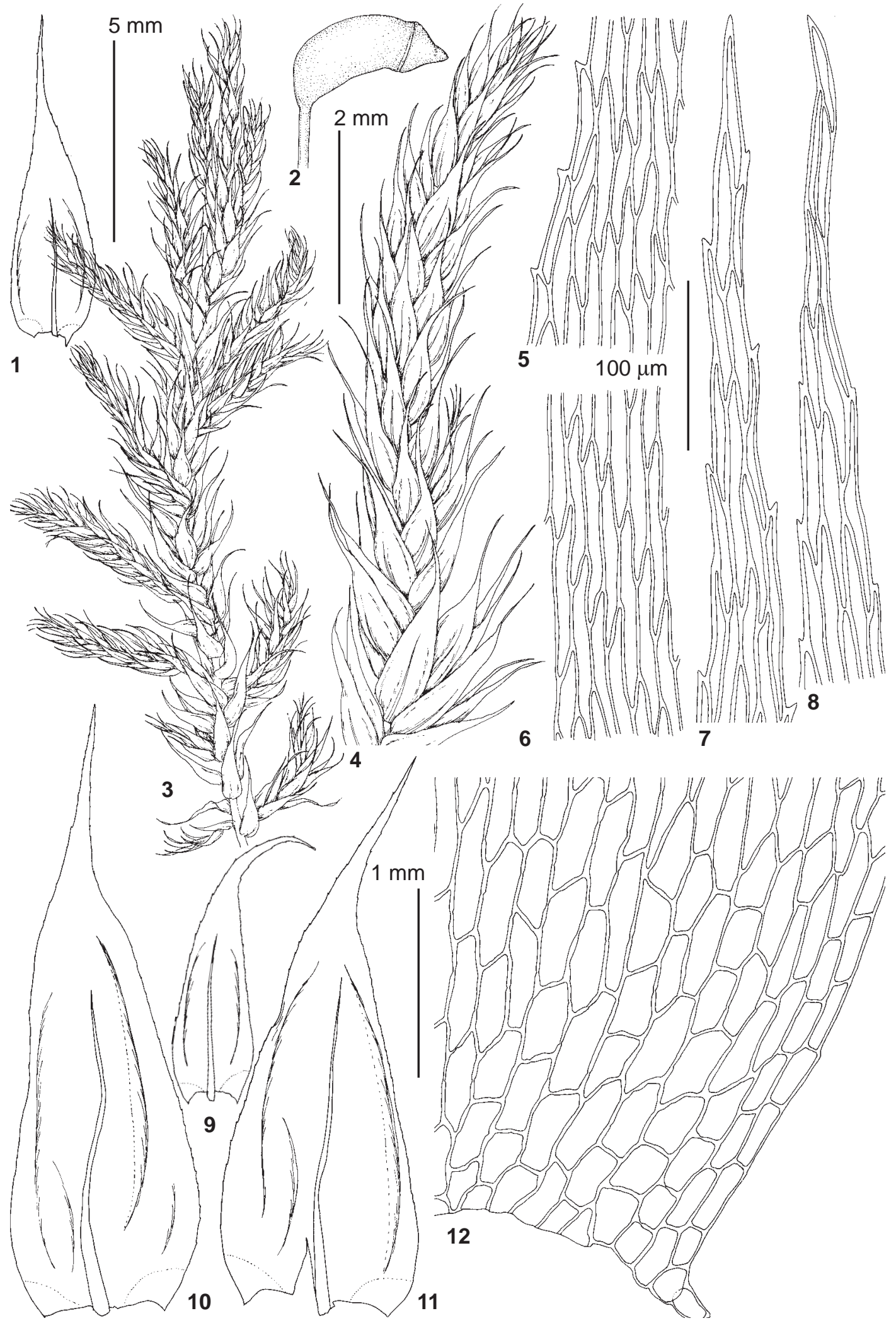


2a. Brachythecium complanatum Broth. remained for a long time a little-known species, while Ignatov (1998) and Ignatov \& al. (2006) found it to be not so rare in south Siberia and occurring also in Japan.

This is a distinct species characterized by the following combination of characters: plants glossy, foliage somewhat subcomplanate in loose growth, while julaceous in dense growth, leaves strongly crumplingly plicate, margin coarsely serrate above, seta strongly rough, calyptra hairy (hairs few), sexuality dioicous.

This species grows usually in mesic or moist forests, while $B$. campestre is primarily a species of open habitats.

Its position in the clade formed mostly by $B$. campestre provides a novel idea of its affinity, but also indicates that morphologically distinct species may not be resolved by ITS (cf. Figs. $1 \& 2$ for B. salebrosum and near species).

3. Brachythecium buchananii-group, including Brachythecium extremiorientale, sp. nova.

This group includes two widespread and polymorphic species, B. buchananii in East and SouthEast Asia and B. ruderale, ranging from the southern states of U.S.A. to West Indies and South America. Buck (1999) suggested that the widespread tropical African B. implicatum (Hornsch. ex Müll. Hal.) A. Jaeger is a synonym of $B$. ruderale; O'Shea (2006) continues to use the former name; regardless the final decision on their identity, these two taxa are closely related. This group includes also West Indian B. zanonii W.R.Buck, East Asian B. kuroishicum and B. garovaglioides, Malesian B. lamprocarpum, and a number of other species with principally temperate and tropical distribution.

Superficially, the plants of this group are distinct, in being strongly lustrous (i.e. more than usually in B. albicans, B. salebrosum, etc.) and in having a rather broad basal part of the leaf that tapers more or less abruptly to a narrow acumen. McFarland (1988) in his Ph.D. thesis segregated them in a separate section, but never formally validated it. In addition to leaf shape he mentioned as an important characters the little-differentiated annulus, which is true for most of its species. At the same time, a dioicous sexual condition is not a characteristic of all species of this group.

Field studies in Primorsky Territory in the Russian Far East revealed a locally common species that still has no name. By both appearance and ITS analysis, it belongs to this group. The fact that it had remained undescribed up to now is readily explained: in the key of Brachythecium for Japan and adjacent areas by Takaki (1955) it keys out as B. salebrosum, a species that appears to be absent or at least very rare in East Asia. Certainly, separation from this species would be difficult, considering the enormous variability of $B$. salebrosum globally. However, the rich goldenlustrous plants with non-plicate leaves (though plicae may appear in microscope slides due to concavities) with long acumina, along with the indistinct square group of smaller cells in the corners of the leaves, make this unnamed species rather distinct from B. salebrosum. In addition, ITS data also indicates that its position is in the 'buchananii-group'.

Brachythecium extremiorientale Ignatov, sp. nov. Fig. 5, 9.

A habitu, plantis pernitentibus, foliis concavis abrupte acuminatis et ITS sequentia species haec appropinquat Brachythecium buchananii gregem, praecipue B. kuroishicum inflorescentiis monoicis, sed marginibus foliorum distincte serratis, sensim acuminatis et cellulis basalibus dilatatis iam dignoscenda.

Typus: 'Russian Far East, Primorsky Territory, Ussurijsky State Reserve, Kamenka Creek, $43^{\circ} 39^{\prime} \mathrm{N}-132^{\circ} 21^{\prime} \mathrm{E}, 150 \mathrm{~m}$ alt., on rotten $\log$, 28.IX.2006 M. Ignatov \& E. Ignatova 06-2935' (holotypus MHA).

Plants moderately robust, in loose to moderately dense tufts, yellowish to brownish green. Stems to $6 \mathrm{~cm}$, prostrate, or ascending in dense growth, terete foliate, irregularly to moderately regularly pinnate branching; branches often deviating from stem by a narrow angle, to $6 \mathrm{~mm}$, straight, terete foliate. Stem leaves imbricate, erect to erectappressed, with acumens usually straight, 2.5-3.2 x 0.9-1.3 mm, ovate-lanceolate (broadest at about

Fig. 5. Brachythecium extremiorientale (from the holotype, Ignatov \& Ignatova \#06-2935, MHA): 1, 9 branch leaves; 2 - capsule; 3-4 - habit; 5-6 - mid-leaf cells; 7-8 - upper leaf cells; 10-11 - stem leaves; 12 basal leaf cells. Scale bars: $5 \mathrm{~mm}$ for $3 ; 2 \mathrm{~mm}$ for $4 ; 1 \mathrm{~mm}$ for 1, 9-11; $100 \mu \mathrm{m}$ for 5-8, 12 . 


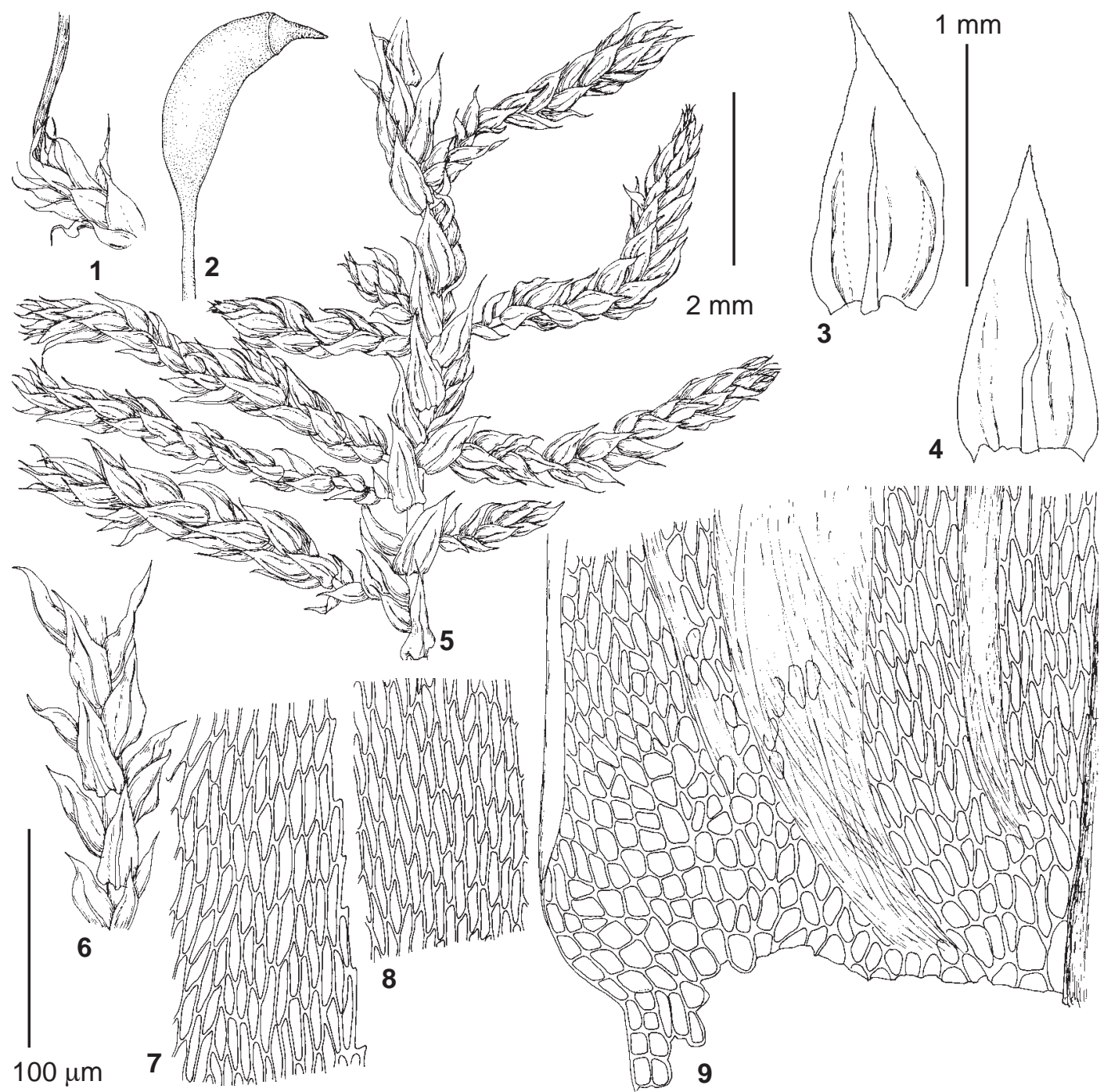

Fig. 6. Brachythecium laetum (from the lectotype of Brachythecium digastrum, CANM): 1 - perichaetium; 2 - capsule; 3-4 - stem leaves; 5-6 - habit, dry; 7-8 - mid-leaf cells; 9- basal leaf cells. Scale bars: 2 mm for 1$2,5-6 ; 1 \mathrm{~mm}$ for $3-4 ; 100 \mu \mathrm{m}$ for 7-9.

$1 / 7$ of leaf length), concave, gradually to abruptly acuminate, below broadest point of leaf only slightly and gradually narrowed to leaf insertion, narrowly decurrent and decurrencies rarely come off with detached leaves, concave, not to weakly plicate (but with stronger pseudo-plicae in slides); margins plane or occasionally recurved in some areas, serrulate to serrate; costa slender, reaching 0.5-0.7 of leaf length, ending without a spine; laminal cells $80-130$ x 6-9 $\mu \mathrm{m}$; basal cells homogeneous across whole leaf base, shorter, to 50-80 $\mu \mathrm{m}$ long, and quite broad, to $20-25 \mu \mathrm{m}$; basal cell walls thin, but looking rigid and somewhat pitted. Branch leaves smaller and narrower, usually more strongly serrate. Sexual condition autoicous. Seta 15-20 $\mathrm{mm}$, smooth. Capsule inclined to horizontal, curved, short-elongate, ca. $15 \mathrm{~mm}$ long, operculum conic, annulus poorly developed and hardly separated. Spores 13-16 $\mu \mathrm{m}$.

Brachythecium kuroishicum, a moderately rare moss and rather strictly confined to the Pacific coastal zone in Asia, is most similar to B. extremioientale in both habit and autoicous sexuality that is relatively rare in this group. However $B$. kuroishicum has leaves more abruptly tapered to linear, 'cirriphylloid' acumina, subentire leaf mar- 
gins, and large cells confined to the leaf corners, not across the whole leaf base.

Basal cells that are rather even across the leaf base are somewhat similar to those of B. garovaglioides, but this species is much more robust, has leaves with broadly ovate basal part and is dioicous.

Specimens examined: Primorsky Territory: Usurijsky State Reserve Ignatov \& Ignatova 06-2335, 2340, 2345 (MHA); Chuguevsky Distr., Ignatov 07-557 (MHA); Sakhalin Province: Kuril Islands, Kunashir, Ignatov 06-1793; 06-3161; 06-3189 (MHA).

Brachythecium extremiorientale grows at low elevations, usually 100-700 m, on tree bases and fallen logs and stumps in forest (usually in mixed north-temperate type) in shallow valleys, and in the Kuril Islands on Hydrangea stems within Sasa communities.

3a. Brachythecium buchananii new to Europe.

The species is very common in China and Japan, but the fact that it was recognized in Russia only recently (Ignatov \& Afonina, 1992) clearly indicates the low level of exchange of taxonomic concepts across biogeographic and sometimes also political borders. After its first records from south Siberia, this species was found to be common in the southern part of Asian Russia, penetrating as far north as Central Kamchatka (Czernyadjeva, 2005) and central Yakutia, $61^{\circ} \mathrm{N}$ (Krivoshapkin et al., 2001). The known western limit of the species was in Altai in Russia, Uzbekistan in Middle Asia (Ignatov \& Ignatova, 2003), and Pakistan (Nishimura \& Higuchi, 1993).

Collections of the species from the Middle Ural Mountains in Perm Province were made recently by Andrey Bezgodov. Brachythecium buchananii was collected on the banks of Chusovaya River, along a stretch of ca. $6 \mathrm{~km}$ on several individual cliffs formed by Upper Devonian limestone, on cliff bases and ledges. They are represented by very small plants, especially similar to those from Altai and Kamchatka, and would be difficult to interpret by morphology only. As all the leaves are narrow and similar to branch leaves of more southern populations, and have more serrulate margins (again, a similarity to branch leaves). Takaki (1955) described a similar morphotype as B. buchananii var. gracile Broth.; its real taxonomic value, however, needs further studies in the context of the study of the 'buchananii-group' as a whole.
Specimens examined from Europe: Perm Province, Lys'va Distr., Chusovaya River downstream from KynZavod: cliff “Stenovoy", 5753'N-58 $41 \mathrm{E}, 260 \mathrm{~m}$ alt., 9.VIII.2005 Bezgodov \#111; cliff “Pechka”, 5752'N$58^{\circ} 42^{\prime} \mathrm{E}, 200 \mathrm{~m}$ alt., 11.VIII.2005 Bezgodov \# 176; cliff

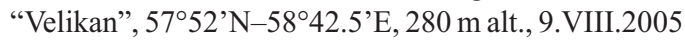
Bezgodov \#79; cliff “Ostryak”, 5753'N-5844'E, 240 m alt., 12.VIII.2005 Bezgodov \#184; cliff "Denezhnyy", $57^{\circ} 52^{\prime} \mathrm{N}-58^{\circ} 41^{\prime} \mathrm{E}, 180 \mathrm{~m}$ alt., 9.VIII.2005 Bezgodov \#61 (all in MHA and PPU).

\section{Brachythecuim laetum and B. digastrum,} Fig. 6.

Brachythecium laetum (Brid.) Bruch, Schimp. \& Gümbel, Bryologia Europaea 6: 24. Fig. 554. 1853. - Hypnum laetum Brid., Bryologia Universa 2: 479.1827.

Brachythecium digastrum Müll. Hal. ex Kindb., Catalogue of Canadian Plants, Part VI, Musci 190. 1892. Lectotype (designated here): "North American Mosses, Herbarium of Columbia College, Named By E.G.Britton-A.J.Grout, 345. Brachythecium digastrum CM \& K. On earth, McKay's Bush, Ottawa, Ont., Oct. 12th $1889 \mathrm{~J}$. Macoun (CANM!)". Syn. nov.

Brachythecium digastrum was described by Carl Müller and Kindberg in Macoun's Catalogue of Canadian plants (Macoun, 1892). It was compared with B. biventrosum (Müll. Hal.) A. Jaeger (=B. acuminatum), from which it differs in more robust plants, and with $B$. laetum. The differences of $B$. digastrum from the latter species include leaves that in $B$. digastrum are short acuminate (vs. long acuminate in B. laetum), rigid (vs. soft), not shining (vs. shining) and, when dry, loosely appressed or sub-imbricate (vs. patent). All these characters are highly variable in $B$. laetum and can hardly be sufficient for the segregation of a separate species. Plants from dry places usually have shorter leaves and such short cells that their separation in a sterile state from B. acuminatum may be quite difficult. This resulted, among others, in the misinterpretation of the type of Hypnum (Brachythecium) oxycladon, (cf. Robinson \& Ignatov, 1997).

The protologue of $B$. digastrum mentioned that the species is monoicous, but sexuality was not used to distinguish it from $B$. laetum, because $B$. laetum was also considered by those authors to be monoicous. Moreover, they poined out that Lesquereaux \& James were wrong in describing 


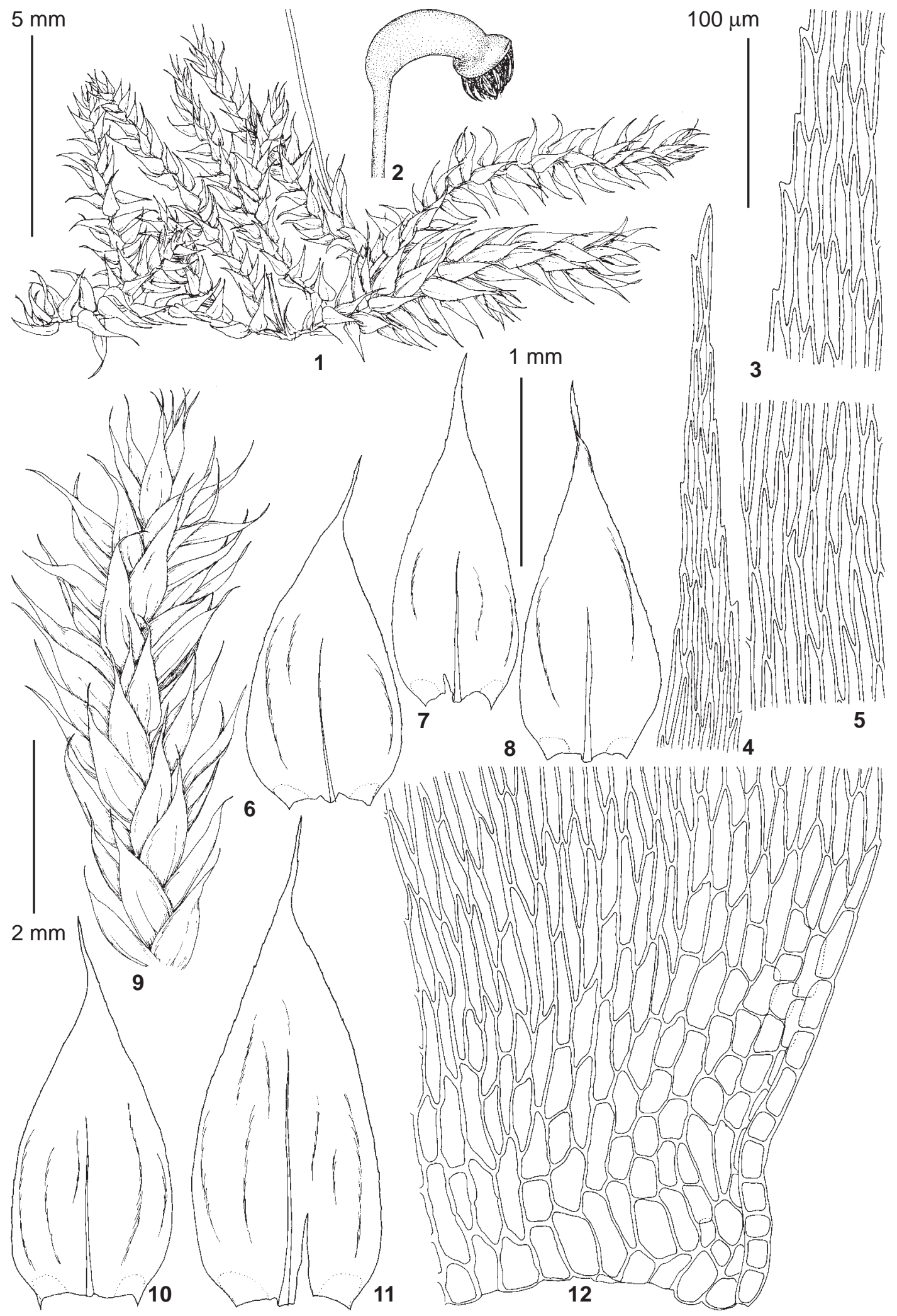


B. laetum as a dioicous species, and that it is in fact autoicous). It is not clear why the sexuality of these species was so confusing. One of the possible explanations could be that undeveloped 'branch buds' of B. laetum are superficially quite similar to perigonia. Soon after, the sexual condition of B. laetum was correctlt described by Grout (1897), who, however, did not totally reject the opinion of Carl Müller and Kindberg, and described B. laetum (sub. B. oxycladon) as 'dioicous, rarely monoicous'. All subsequent authors do not mention that a monoicous condition in this species is possible. At the same time, the characteristic of $B$. digastum as monoicous remains in Grout (1897), as well as in all subsequent publications (Grout, 1928; Robinson, 1962; Crum \& Anderson, 1981, etc.), and was used as an additional or the main evidence for recognition of this taxon. The holotype of Hypnum digastrum has only female plants, thus leaving no character for separation it from $B$. laetum. And finally, one specimen from West Virginia with typical ' $B$. digastrum appearance' was included in our molecular analysis and appeared within the clade with two 'typical B. laetum' .

5. Brachythecium boreale Ignatov sp. nov. Fig. 7, 9.

Species haec habitu, marginibus foliorum ubique serrulatis et inflorescentiis monoicis Sciuro-hypno oedipodio similis, sed tamen ITS sequentia et setis glabris genero Brachythecium, praecipue B. mildeano affinis, sed ab altero marginibus folii serrulatis, foliis abrupte acuminatis et cellulis alaribus magis delimitatis recedit.

Type: 'East Siberia, Republic Saha/Yakutiya, Ust-Maya District, Solnechny, Tom Creek, $60^{\circ} 14^{\prime} \mathrm{N}-139^{\circ} 39^{\prime} \mathrm{E}, 650 \mathrm{~m}$ alt., on rotten $\log$ in Larix forest, 2.IX.2000 M. Ignatov 00-1074' (holotype in MHA).

Plants medium-sized to moderately robust, in loose to moderately dense tufts, yellowish to brownish-green, in exposed habitats fading to stramineous. Stems to $6 \mathrm{~cm}$, prostrate, rarely ascending, terete foliate, irregularly, often fasciculately branching; branches to $6 \mathrm{~mm}$, straight, terete foliate. Stem leaves imbricate, erect to erecto-patent,
1.8-2.4 x 0.6-0.9 mm, ovate (broadest at about $1 /$ 7 of leaf length), abruptly acuminate, below the broadest point of leaf rounded to leaf insertion, narrowly and shortly decurrent, decurrencies rarely come out with detached leaves, concave, not to strongly plicate; margins plane or recurved in some areas, serrulate all around; costa slender, reaching 0.4-0.6 of leaf length, ending in a small spine or without it; laminal cells $45-80$ × 6-8 $\mu \mathrm{m}$; basal cells near costa broader and shorter in a few rows, large in leaf corners, forming an indistinctly delimited conspicuous, pellucid group. Branch leaves somewhat smaller, but otherwise similar. Sexual condition autoicous. Seta 15-20 mm, smooth. Capsule inclined to horizontal and curved, ca. $20 \mathrm{~mm}$ long, operculum conic, annulus separated at places. Spores ca. (18-)20-25 $\mu \mathrm{m}$.

The species is the most common in the central Yakutia, growing on soil in Larix and Alnus forests, while in the Arctic it grows among willow shrubs. Most collections are from the forest belt (which has an upper limit at ca. $700 \mathrm{~m}$ in this region at $60^{\circ} \mathrm{N}$ ), but occasional collections are from as high as $1600 \mathrm{~m}$ (in sheltered places near cliffs).

The northern populations of this species are superficially similar to Sciuro-hypnum oedipodium and sometimes even $S$. curtum due to the triangular and more or less spreading leaves. The autoicous sexual condition and enlarged basal cells also support such a relationship and the plants were first thought to be an unusual Sciuro-hypnum with a smooth seta. More southern populations, however, have longer and more concave leaves, resulting in a 'cirriphylloid' appearance; in habit they are somewhat similar to B. udum (see below), but that species has subentire leaves, a character that has been never observed in $B$. boreale.

Poorly developed Brachythecium boreale with relatively narrow leaves can be confused with $B$. baicalense, as both are autoicous, have enlarged cells in the leaf corners and serrulate leaf margin. In the presence of sporophytes, the former species can be recognized by large spores, 20-25 vs. 15-17 $\mu \mathrm{m}$. When plants are sterile, the most reliable characters are relatively short cells in $B$. boreale, rarely longer than $80 \mu \mathrm{m}$ while in $B . b a$ -

Fig. 7. Brachythecium boreale (from the holotype, Yakutia, Ignatov 00-1074, MHA): 1, 9 - habit, dry; 2 capsule; 3, 5-mid-leaf cells; 4 - upper leaf cells; 6-8 - branch leaves; 10-11 - stem leaves; 12 - basal leaf cells. Scale bars: $5 \mathrm{~mm}$ for $1 ; 2 \mathrm{~mm}$ for 2,$9 ; 1 \mathrm{~mm}$ for $6-8,10-11 ; 100 \mu \mathrm{m}$ for $3-5,12$. 


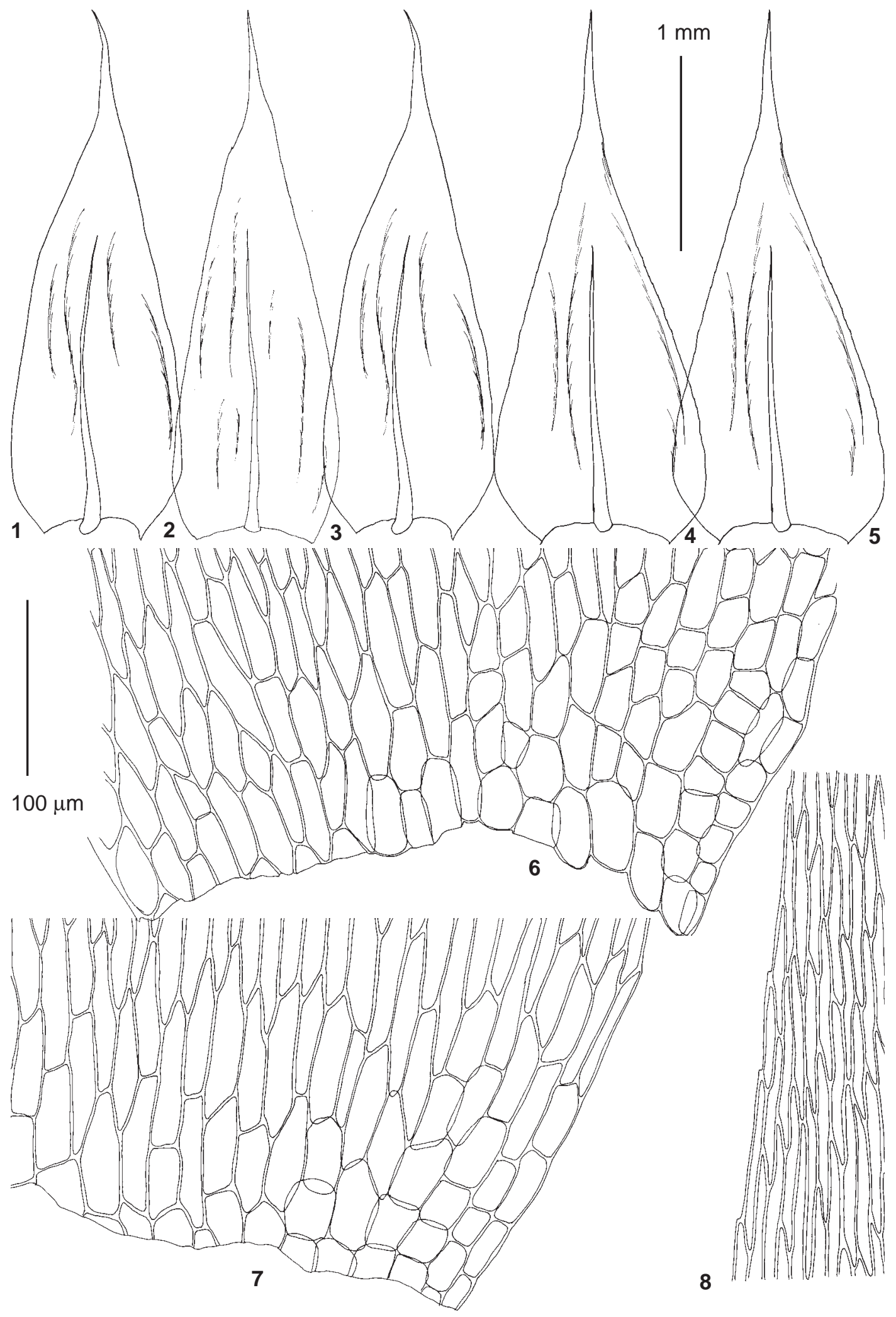




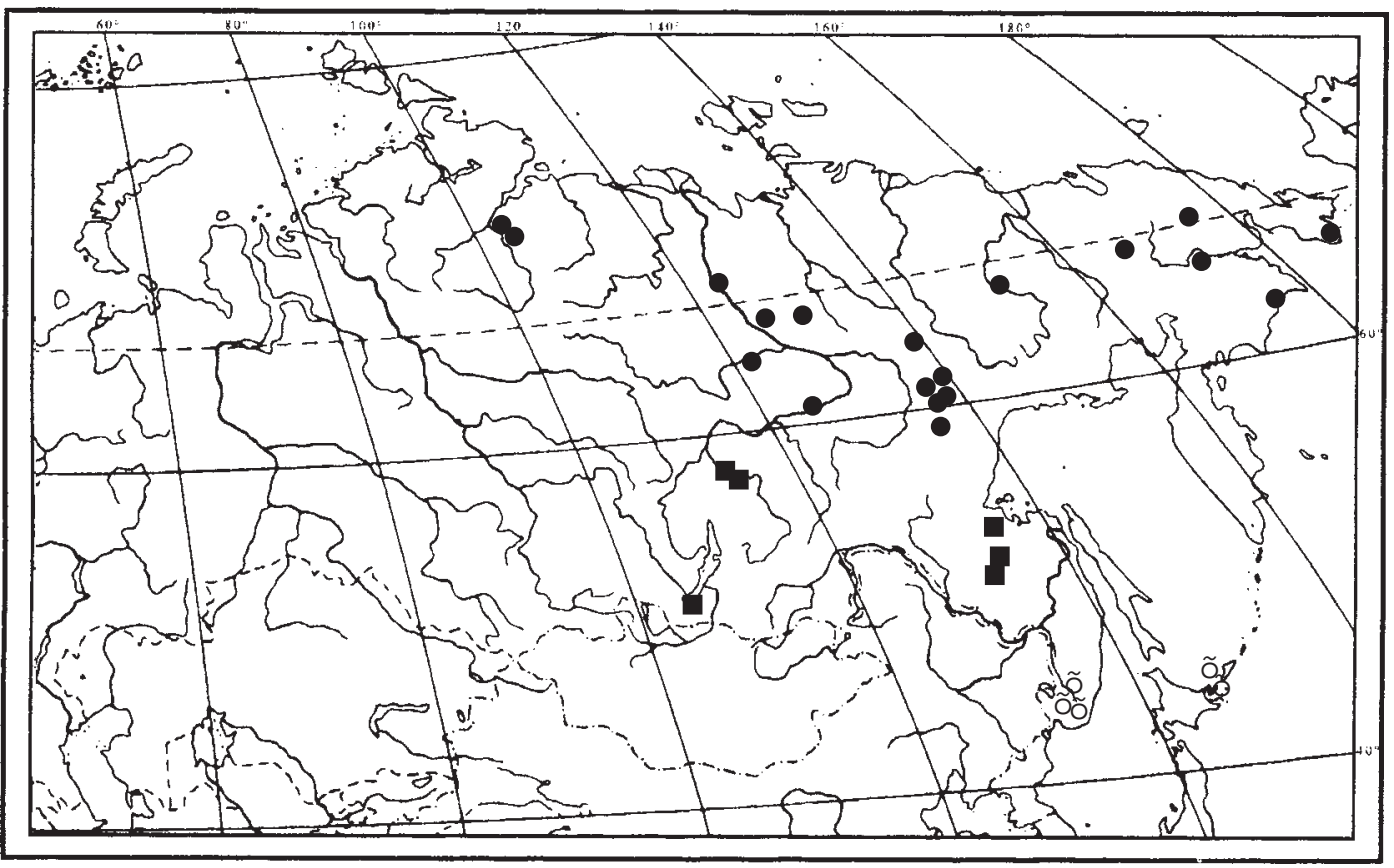

Fig. 9. Distribution of new species: Brachythecium baicalense $(\boldsymbol{\square}), B$. boreale $(\bullet)$, and B. extremiorientale (0̃).

icalense many median laminal cells are longer than $100 \mu \mathrm{m}$. Also leaf serration is different: teeth in the former species are of moderate size and fairly regular along the leaf margin, whereas in the latter the marginn is sharply serrate. In addition the decurrency in $B$. boreale is inconspicuous compared with $B$. baicalense (cf. Figs. 3 and 7).

ITS data clearly indicate the position of $B$. boreale near B. laetum, B. acutum and B. mildeanum. The morphological justification of such a grouping is absent as these species have little in common (except for B. acutum and B. mildeanum).

Specimens examined: Chukotksy Autonomous District: Inachpak Cape, Afonina 29.VIII.1001 (MHA ex LE); Anadyr Distr., Yuzhny Pekulneiveem, Afonina 5.VIII.1979, 13.VIII.1979 (MHA ex LE); Anadyr Distr., Yuzhny Pekulneiveem, Afonina 22.VII.1979 (MHA ex LE); upper course of Tanyurer River, Afonina 15.VII.1979 (MHA ex LE); Baran'e Lake, Afonina 25.VII.1980 (MHA ex LE); Yablon River, Afonina 10.VIII.1982 (MHA ex LE). Yakutia: Khangalassky Distr., Lenskie Stolby, Ignatov 00-831, 00-790 (MHA); Kobyaisky Distr., upper course of Undyulyung River, Imgalan Creek, E.V. Baryshev 8.VII.1990 (SASY ex MHA); Tomponsky Distr.: Suntar-Khayata, 227 km from Khandyga to Oimyakon, Ivanova \& Krivoshap- kin, 18.VI.1999 (MHA); Ust-Maya Distr.: KhatunYuryakh Creek, Ignatov 00-1068, 00-1069 (MHA); Solnechnyy, Ignatov 00-1064, 00-1070 (MHA); Tarbagannakh Creek, Ignatov 00-1068 (MHA); Tom Creek, Ignatov 00-1066, 00-1074 (MHA); Yugorenok Creek, Ignatov 00-1058, 00-1059 (MHA); Verkhnekolymsky Distr., Kolyma River near Ochegino Creek mouth, E.I.Ivanova 31.VII.1992 (SASY ex MHA); Vilyuj Distr., A. Permyakova \& L. Dobretsova 1958 (SASY ex MHA); Zhigansk Distr., lower course of Undyulyung River, E.V.Ivanova 24.VI.1990 (SASY ex MHA); Zhigansk Distr., Lena River near Kystatemka Creek mouth, L. Dobretsova 25.VI.1958 (SASY ex MHA). Taimyr Municipal District: Anabar Plateau, Medvezhya River, Fedosov 05-31, 05-650 (MW); Fomich River, Fedosov 06-604 (MW).

\section{Brachythecium mildeanum and B. acutum.} Fig. 8.

The identity of $B$. acutum that was described from eastern North America was controversial. European authors either included $B$. acutum in $B$. mildeanum (Limpricht, 1896), or considered the former to be a variety of the latter (Podpera, 1954). Most North American publications, however, included B. acutum in B. salebrosum (Robinson, 1962; Crum \& Anderson, 1981).

Fig. 8. Brachythecium acutum (1-3, 7 - from Illinois, Allen, 6157, MO; 4-6, 8 - from New York State, Leonardi BB-50, MO): 1-5 - stem leaves; 6-7 - basal leaf cells; 8 - mid-leaf cells. Scale bars: $1 \mathrm{~mm}$ for 1-5; $100 \mu \mathrm{m}$ for 6-8. 
Grout (1928) discussed these two species, concluding that the North American B. acutum is distinct from the common and widespread European B. mildeanum in its usually loose foliage and flaccid branches (B. mildeanum has dense foliage and turgid branches). This is generally true, although the variation of both species overlaps. Also $B$. acutum is autoicous, and only rarely polyoicous, while $B$. mildeanum is usually described as polyoicous: plants can be synoicous, autoicous, and unisexual, and then usually male; however, many collections of both species are sterile, and many collections from Asian Russia and Western Europe are autoicous.

One more characteristic and constant feature of $B$. acutum is the unusually long seta, $3-4 \mathrm{~cm}$ long; most collections of $B$. mildeanum from Europe have setae 2(-2.5) cm, although Limpricht (1896) gave its length as 'usually $2(-2.5) \mathrm{cm}$, rarely $4 \mathrm{~cm}$ ', and especially mentioned one locality where this $B . \mathrm{m}$. var. longiseta Warnst. occurs. Plants with setae of $3.5-4 \mathrm{~cm}$ were issued in Bryophyta Danica Esc. \#283 (coll. Hesselbo 3.IX.1907, LE!).

The study of herbarium collections from North America revealed that $B$. acutum is no less distinct from $B$. salebrosum than B. mildeanum. Certainly, all three species are extremely variable. Sometimes, especially in dry habitats, B. acutum has rather small cells in the leaf corners, resembling those of $B$. salebrosum. Similar variation is known in B. mildeanum as well. At the same time, most Brachythecium species growing in very wet or flooded habitats develop alar cells that are larger than usual; a good example of this was shown in cultivation experiments with Brachythecium rutabulum (Wigh,1975).

A rather constant character in B. acutum is the pattern of serration: each marginal cell ends in a small but distinct tooth, whereas in B. mildeanum the leaves are entire, subentire, or very rarely slightly serrulate, but without a regular pattern.

ITS data clearly demonstrate the close affinity of $B$. acutum with $B$. mildeanum, as well as their distant position from B. salebrosum (Fig. 1). However, if the latter statement seems rather clear (mostly due to good correspondence with morphology), the position of $B$. acutum and $B$. mildeanum in one common clade should probably not be interpreted in favor of their immedi- ate synonymy. The analysis (Fig. 1) combined $B$. campestre with $B$. complanatum, B. salebrosum with $B$. erythrorrhizon, B. brandegei, and $B$. glareosum; and B. turgidum with B. udum; the species status of all or at least most of them is unquestionable.

The present data just point out the necessity of a thorough comparison between the species, and if they were confirmed as two independent species, then their distribution has to be elucidated, as the present observations do not exclude the occurrence of B. acutum in Europe.

In North America, B. acutum has a scattered distribution, mainly in the eastern regions, from Newfoundland and Nunavut southward to Missouri and Illinois, while in the mountains of the West it penetrates to the south into Utah and California (in the latter maybe recently introduced). It grows on wet soil and peat in fens or swamps, occasionally on rotten logs in swampy forests at $0-1000$ m elev.; one collection from $3650 \mathrm{~m}$ in Colorado is also tentatively attributed to this species.

Selected specimen studied (with the state/province abbreviations of BFNA, specimens in $\mathrm{MO}$, if otherwise not indicated): B.C. (Grout, North American Musci Perfecti,\# 15), Man.(Hand 932), Nfld. (Buck 52529), Nunavut(Sutton, year 1930), Ont. (Macoun, Canadian Mosses \#288), Que. (Dupret 2.I.1926), Sask. (Bourgeau, year 1985), Yukon(North American Mosses, R.S.Willams \#716), Alaska (Trelease \& Saunders 14.VI.1899), Calif. (Habeeb 1411, on lawn in Los Angeles), Colo. (Grout, North American Musci Perfecti 447; Hermann 27141), Del. (Reed 131703), Idaho (McFadden 19102), Ill. (Allen 6157), Ind. (Flowers 3040, NY), Iowa (Conard 23.VI.1942), Maine (Allen 27503), Mo. (Allen 26741), Mont. (Montana mosses, R.S. Williams 385), Nebr. (Churchhill 11878), N.J. (Austin, Musci Appalachiani 316), N.Y. (Grout, North American Musci Perfecti 213), N.Dak. (Ikenberry 218), Ohio (Environm. Control Group 5, 6-20.V.1972), Pa. (Rau, s.n.), S.Dak. (Allen 3601), Utah (Flowers 3244), Wyo (Nelson 1698).

Brachythecium acutum is distinct from $B$. salebrosum in having lax, homogeneous areolation across the leaf base (vs. differentiated small cells in leaf corners), straight and often conspicuously triangular leaves (Fig. 6: 4, 5), i.e., gradually tapered from the broadest point upward (vs. more or less falcate leaves that are usually narrow, and if broad, then acuminate), small but sharp teeth all along the leaf margins (vs. serrulate to serrate 
above), usually not or only weakly plicate leaves (vs. usually plicate), and unusually long setae, 3$4 \mathrm{~cm}$ long (vs. ca. $2 \mathrm{~cm}$ ).

7. Brachythecium rotaeanum. Figs. 10-11. Ignatov (1998) found that this species is very common in the Altai Mountains in Russia, whereas B. salebrosum is a rare in this region. Subsequent studies demonstrate that almost all collections from Asian Russia identified in herbaria as B. salebrosum belong to $B$. rotaeanum. The latter species is especially common in the hemiboreal zone of Asia, while B. salebrosum is rare in the eastern part of Asian Russia, having a scattered distribution mainly in boreal areas.

Most of the northern Chinese and Mongolian collections of B. salebrosum were also re-identified as $B$. rotaeanum. Finally, a similar situation was found also in eastern North America: B. salebrosum is more or less widespread in the West, but is a rare species in eastern North America, where it is confined to the northern areas (Newfoundland), while it is totally absent in the main part of the territory covered in Crum \& Anderson's (1981) flora. Most of so-called herbarium collections from the latter area were sorted among B. acutum and $B$. rotaeanum (cf. Robinson, 1962). Being very common in the eastern North America, B. rotaeanum is occurs in western North America as well, but is uncommon there.

Selected North American specimen studied (with the state/province abbreviations of BFNA, specimens in MO, if otherwise not indicated): B.C. (Brinkman 15.V.1921 in McFadden Herb \#19933), N.B. (Habeeb 21211), Ont. (Ireland 21876), Ala. (Earle \& Baker, 4.X.1896), Alaska (Schofield 117749), Conn. (Allen 25996), Del. (Reed 126345), Fla. (Anderson \& Crum 13678; Pursell 300MF5), Ill. (Schoil 319B), Ind. (Haines 160), Iowa (Allen 14973), Ky. (Risk 10233), La. (Reese 8172), Maine (Allen 10163, 21278 [Maine Mosses 70, as B. salebrosum]), Md. (Allen \& Solomon 22938), Mich. (Ikenberry 16.VII.1936), Minn. (Holzinger 16.VI-7.VIII.1902), Mo. (Brant \& O'Donnell 5343), N.Mex. (Weber B-44682), N.Y. (Redfearn 38177), N.C. (Anderson 12612 [Mosses of North America 921, as B. salebrosum]), N.Dak. (Ikenberry ND208B), Ohio (Sullivant 1842), Tenn. (Clebsch 13148), Vt. (Grout 23.VII.1900 [North America Musci Pleurocarpi 127 , as B. salebrosum var.]), Va. (Hunsucker 609), W.Va. (Gray 12.IX.1922), Wis. (Iltis 27848). Specimens from Russia are available from: http://gis-app.ict.nsc.ru/ bio/search.php.
The fact that many collections of $B$. rotaeanum were identified as B. salebrosum is not surprising, as some handbooks did not separated them (e.g., Lawton, 1971; Nyholm, 1965), whereas other authors accepted $B$. rotaeanum with a rather narrow circumscription. For example, Crum \& Anderson (1981) suggested that the most useful characters for separation of $B$. rotaeanum from $B$. salebrosum are the slightly curved and almost erect capsule and its smooth leaves. The latter seems to be based on observation mostly from southeastern U.S.A. where leaves of B. rotaeanum often have no plicae, but this is not a constant character throughout its range. Similarly, the slightly curved capsule is conspicuous in some populations, while its shape is variable in other, and sometimes all the sporophytes do not differ from those of $B$. salebrosum. Robinson (1962) separated B. rotaeanum from $B$. salebrosum mainly based on the homogeneous basal cells (parallels to B. laetum), and this approach is closer to the circumscription accepted here, although the basal cells should probably not be considered especially similar to $B$. laetum where they are small and opaque, while in $B$. rotaeanum they are rather large. When protected from direct light, $B$. rotaeanum has a pure green and slightly glaucous color, that is often useful for recognition of the plants in the field. This color is more similar to that of B. laetum (when it grows in shade which is not common) than to that of $B$. salebrosum (which is dirty yellow-green in moderate light to more dark-green in deep shade).

Thus, B. rotaeanum differs from $B$. salebrosum in: 1) an indistinctly delimited group of cells in the leaf corners vs. clearly delimited square group of small subquadrate cells; 2) often (but not always) slightly curved capsules vs. always more or less horizontal; 3) leaves lacking a tendency to be falcate vs. often more or less falcate-secund, at least to a some extent; 4) color (as described previously).

The variation of B. rotaeanum follows a somewhat different pattern than in B. salebrosum. In the latter the growth under xeric conditions usually results in a narrower leaves, whereas in $B$. rotaeanum growth under unfavourable conditions produces shorter leaves; the laminal cells are proportionally shorter as a consequence (as illustrated by Hedenäs (1998) for Drepanocladus species). 

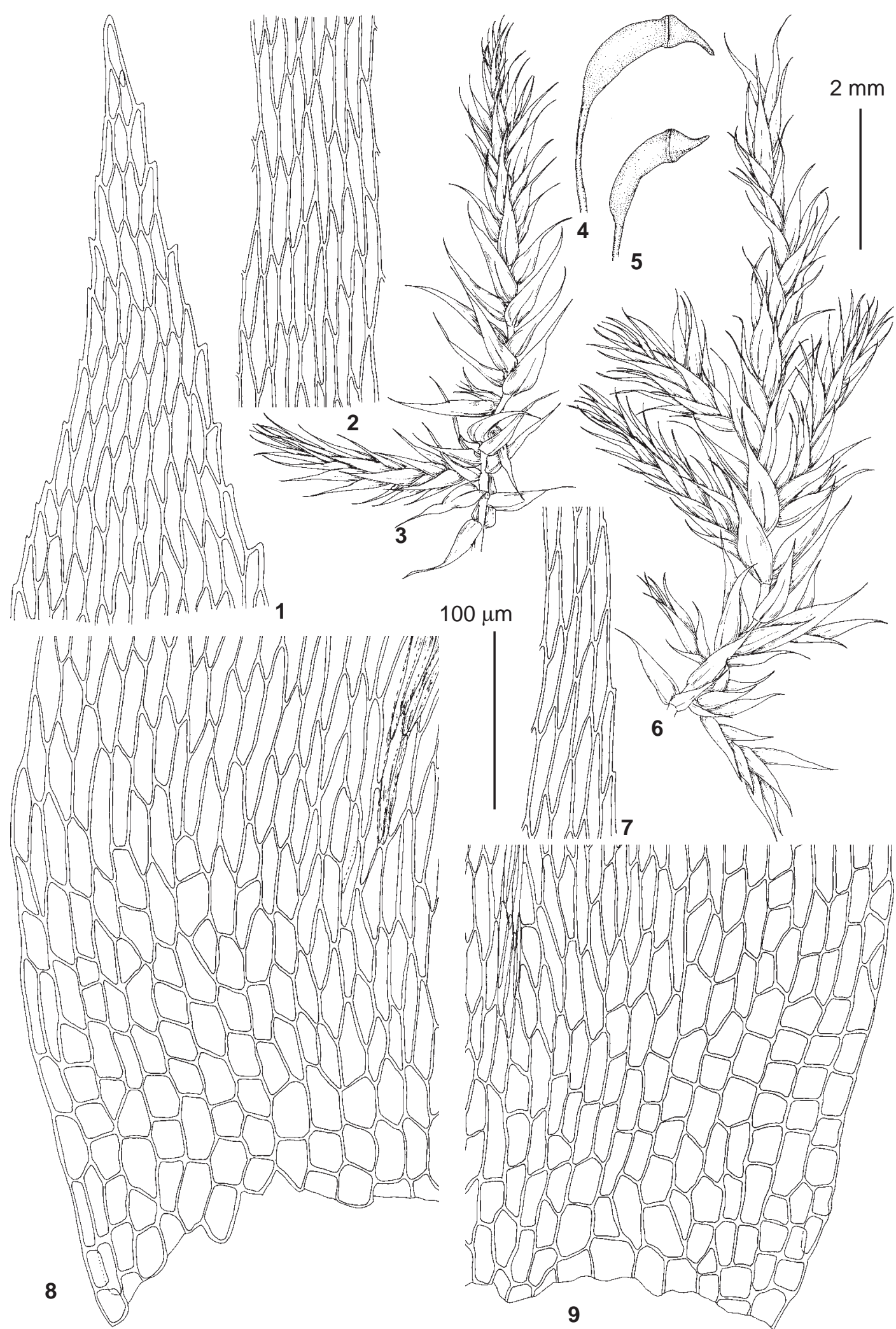

$100 \mu \mathrm{m}$
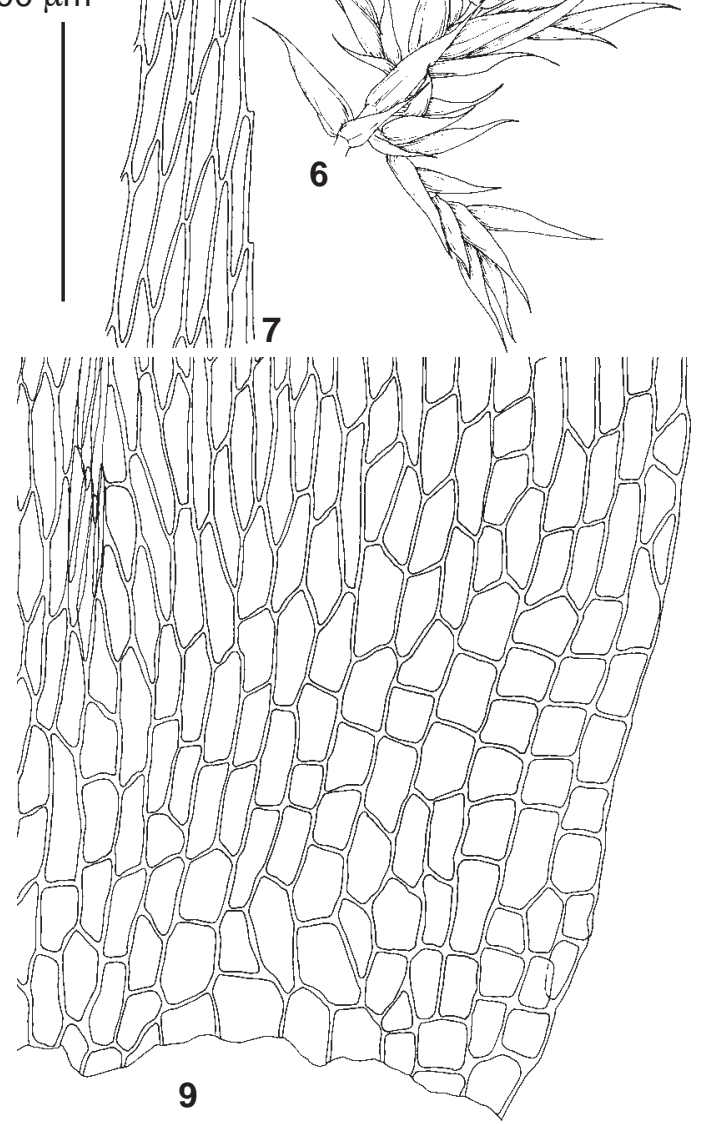

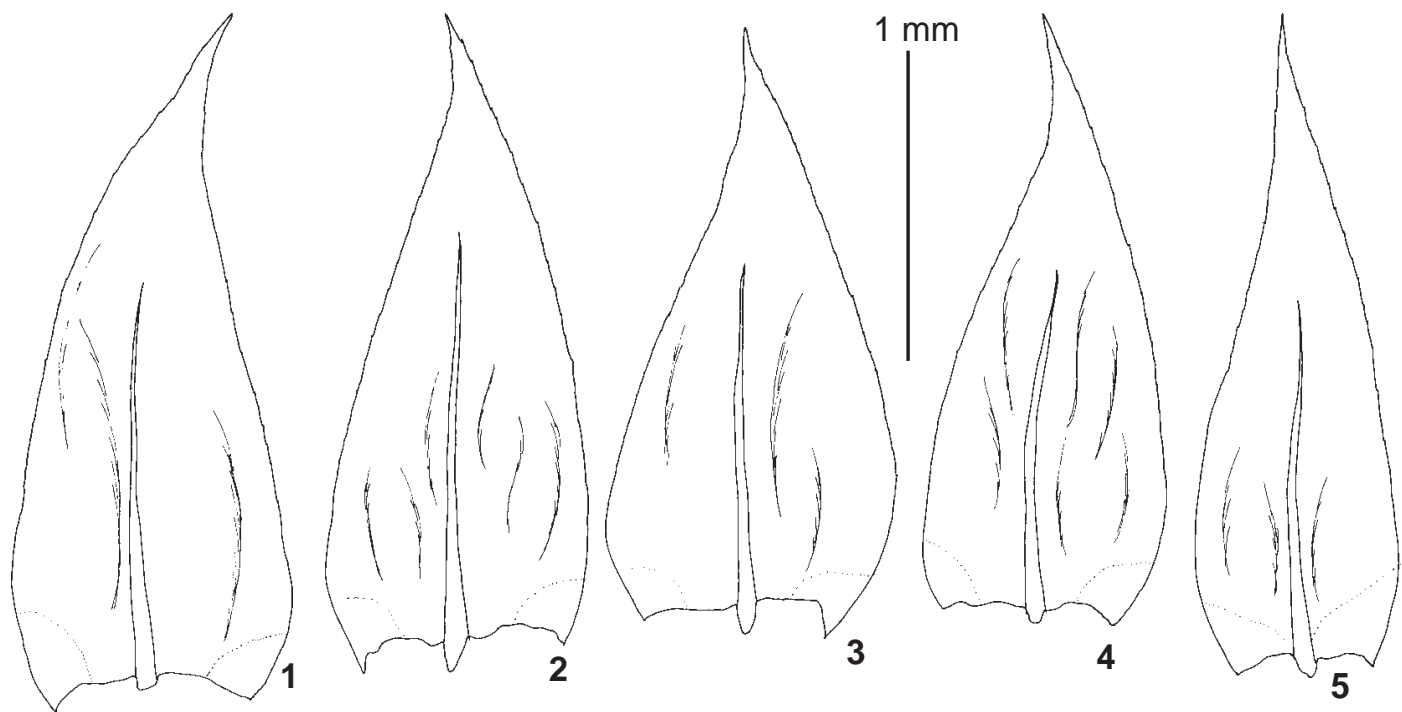

Fig. 11. Brachythecium rotaeanum (1-5 - from type of Brachythecium rotaeanum, Italy, FI); 1-5 - stem leaves. Scale bars: $1 \mathrm{~mm}$ for 1-5.

Fig. 10 (page 132). Brachythecium rotaeanum (1-4 - from type of Brachythecium rotaeanum, Italy, FI); 1-3, 8 - from Illinois, Allen, 6157, MO): 1 - upper leaf cells; 2, 7 - mid-leaf cells; 3, 6 - habit; 4-5 - capsules; 8-9 basal leaf cells. Scale bars: $2 \mathrm{~mm}$ for 3-6; $100 \mu \mathrm{m}$ for 1-2, 8-9.

A similar pattern of leaf shape variation is also noted in B. laetum, a species that was considered closely related to $B$. rotaeanum by Grout and Robinson. In addition, $B$. salebrosum has usually a rather consistently expressed leaf serration, whereas margins in $B$. rotaeanum are extremely variable in this character: usually they are serrulate to more strongly toothed in the acumen, but in many collections leaves along one shoot vary from subentire to coarsely serrate distally; however, even in such cases, at least some leaves have a rather distinct serration in their acumina.

In Asian Russia there is no problem recognising $B$. rotaeanum and B. salebrosum, and about $90 \%$ of the collections can be identified under a stereomicroscope (the latter species is rare and not especially variable in the area). In Europe, where B. rotaeanum is rare and B. salebrosum is common and extremely variable, it is more difficult to separate the two, which explain why most of European authors agree that this is a variety and not a species.

Worldwide revisions leave no doubt that $B$. rotaeanum is a valid species. Molecular data support this as well, because five specimens from distant localities (Ural Mountains, Caspian Sea area, Altai in cental Asia, Chukotka, and eastern North
America), all have the same two substitutions in ITS2 and form a clade (Figs. 1, 2).

The species here called Brachythecium rotaeanum is often accepted under the name $B$. capillaceum (F.Weber \& D. Mohr) Giac., Atti Ist. Bot. "Giovanni Briosi” ser. 5, 4: 268. 1947; - Hурnum salebrosum var. capillaceum Web. et Mohr, Bot. Taschenbuch 313. 1807. The type of this name is absent in B (letter of Ludwig Martins of 20 Dec 2007), and before its lectotypification it is safest to use the name $B$. rotaeanum, the type of the latter is illustrated here (Figs. 10-11) and clearly agrees with the present circumscription.

\section{Brachythecium udum.}

This species was described from Scandinavia and according to Hedenäs (pers. comm.) is rather common there in mountain areas. It is a northern species, probably absent in central Europe, and most of European authors did not recognize it as a separate species, but as a variety of $B$. mildeanum (Podpera, 1954). Both species are growing in wet places, have mostly upright shoots, entire or subentire leaf margins, and more or less homogeneous basal leaf cells. However, in contrast to $B$. mildeanum, $B$. udum is dioicous and has less evenly tapered leaves, so their shape is acuminate rather than narrowly acute. Cells in the leaf corners can 

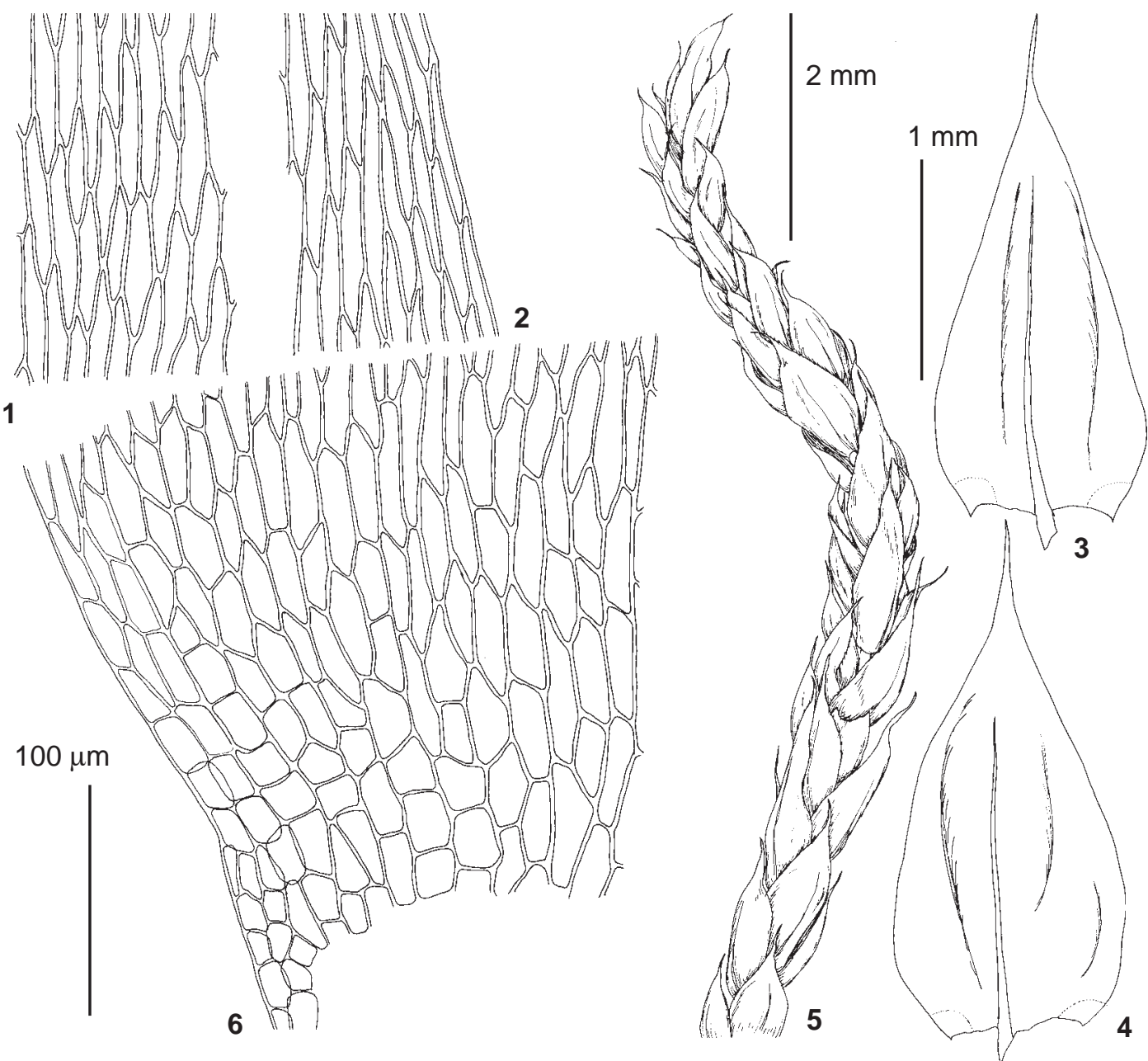

Fig. 12. Brachythecium brandegei (from U.S.A., Colorado, Weber B-114286 (MHA ex COLO); 1-2 - midleaf cells; 3-4 - leaves; 5 - habit; 6 - basal leaf cells. Scale bars: $2 \mathrm{~mm}$ for 5; $1 \mathrm{~mm}$ for 3-4; $100 \mu \mathrm{m}$ for 1-2, 6 .

be somewhat smaller than the juxtacostal cells, or somewhat larger, depending on the environmental conditions.

In Siberia, however, this species is much more common in relatively wet places in cold environments, often in high mountains near snowfields, along brooks, in tundra, etc. Some specimens may pose a question of their distinction from B. mildeanum (especially because of difficulty of sex identification in northern populations where gametangia are often absent). Ignatov (1998) failed to sort them based on morphology in the Altai region. However, further studies confirm their distinction and the present phylogenetic analysis places it in a rather distinct position from B. mildeanum within the Brachytheci- um salebrosum-group; one specimen of $B$. turgidum is in the same clade (Fig. 1). Both B. udum and $B$. turgidum differ from species of the $B$. salebrosum-group by the only one substitution in ITS2, but this substitution is consistently present in all 6 specimens studied.

Brachythecium udum differs from B. turgidum in: (1) sexual condition dioicous vs. autoicous sexual condition; 2) not or only moderately incrassate basal cell walls vs. incrassate to strongly so, and conspicuously pitted; 3) laminal cell walls 1.0$1.5 \mu \mathrm{m}$ thick vs. 2.0-2.5 $\mu \mathrm{m}$ thick; 4) little or moderately plicate leaves vs. strongly plicate. In addition, B. turgidum has a usually easily-recognizable habit: plants are robust and have a more or less rich golden color, while $B$. udum has the size 


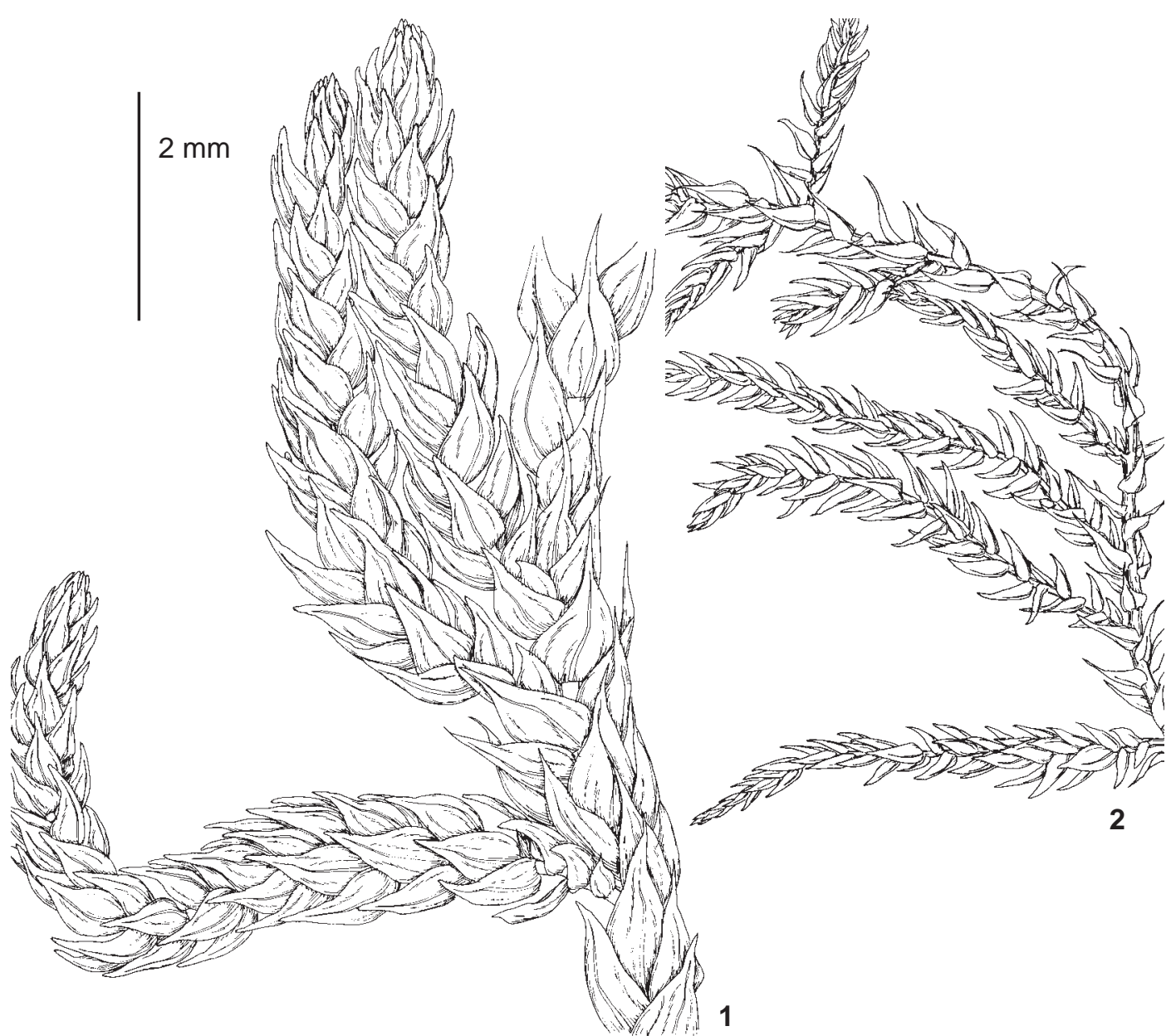

Fig. 13. Eurhynchiastrum pulchellum var. barnesii (Canada, British Columbia, Schofield 85054, MHA ex UBCU, specimen used for sequensing) and E. pulchellum var. pulchellum (Tver Province, Ignatov, 13.VIII.1996, MHA): habit. Scale bar $2 \mathrm{~mm}$ for 1-2.

of 'average' Brachythecium species and is yellowish-green, similar to the 'average' $B$. salebrosum or $B$. mildeanum. When optimally developed, $B$. turgidum can hardly be misidentified as B. udum, but poorly developed plants of the former may be confusing.

Brachythecium boreale is a widespread species in the area where B. udum is also common, and superficially they are often similar. Their distinctions includes, first of all, a leaf margin that is serrulate in B. boreale and (sub)entire in B. udum. In addition, the presence of sporophytes or both perichaetia and perigonia in $B$. boreale usually allow to confirm the autoicous sexual condition, while perigonia in $B . u d u m$ were never found in Siberia.
In addition to northern Eurasia, Brachythecium udum has been found in Steere's collections from Noluck Lake, Alaska, and apparently occurs also in northern Canada.

Selected specimens examined from Russia: Khabarovsk Territory: Verhnebureinsky Distr., Upper Bureya River, 1600 m, Ignatov 97-169 (MHA); 1700 m, Ignatov 97-167 (MHA); Altai Republic: Karakem River, 2300 m, Ignatov 0/379 (MHA); 2700 m, Ignatov 0/1664 (MHA); $2250 \mathrm{~m}$, Ignatov 0/2037 (MHA); Yakutia: Algama River, tributary of Gonam River, 1420 m, Garashchenko 31.VIII.1970 (IRK ex MHA); UstMaya Distr., Allakh-Yun, $600 \mathrm{~m}$, Ignatov 00-893 (MHA); Verkhnekolymsky Distr., Kolyma River 40 km downstream from Zyryanka, E.I.Ivanova 30.VII.1992 (SASY ex MHA). 


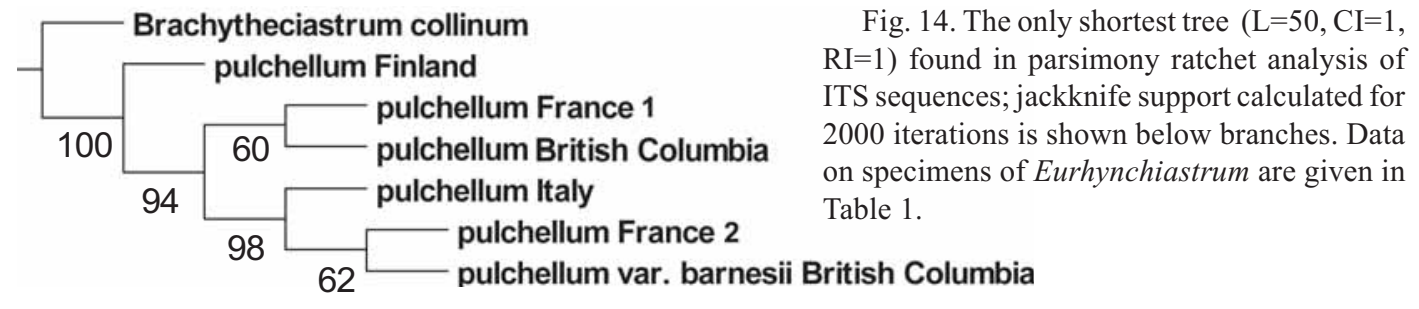

Fig. 14. The only shortest tree ( $\mathrm{L}=50, \mathrm{CI}=1$, $\mathrm{RI}=1$ ) found in parsimony ratchet analysis of ITS sequences; jackknife support calculated for 2000 iterations is shown below branches. Data on specimens of Eurhynchiastrum are given in Table 1 .

9. Brachythecium brandegei (Austin) $\mathrm{H}$. Rob. (Cirriphyllum brandegei (Austin) Grout). Fig. 12.

This species was described from the high mountains of Colorado and is still known from a small area near Summit Lake at Mount Evans in Park Co., Colorado, at 3850-3900 m alt., growing on cliffs and wet soil in mountain tundra. It was issued in exsiccates Crypt. Exs. Museo Hist. Natur. Vindobonensi, \#4165, with the label indicating elevation as $4200 \mathrm{~m}$. This is probably a result of inaccurate transmission of 12700 feet into meter, as according to the same label the species was collected on cliffs at the lake shore, which is at $3850 \mathrm{~m}$.

It is characterized by erect growth, more or less julaceous foliage, concave leaves with short acumina, and lax areolation: the laminal cells are $40-80 \times 8-12 \mu \mathrm{m}$; the basal cells are rather large and homogeneous across the base, and the cells in the leaf corners are somewhat differentiated, being moderately thin-walled and forming pellucid or moderately opaque alar groups of somewhat shorter cells.

Brachythecium brandegei is most similar to $B$. udum, but the single specific substitution that differentiates $B$. udum from the species around $B$. salebrosum is absent in the former species and it is found in the species more closely related to $B$. salebrosum and B. erythrorrhizon (cf. Fig. 1). However these two species have narrower cells, alar groups composed of small cells, the more or less falcate leaves, which suggest keeping Brachythecium brandegei as a separate species.

10. Eurhynchiastrum pulchellum var. barnesii. Fig. 13.

The genus includes one species, E. pulchel$l u m$, that is universally accepted and several other taxa that are accepted as species by some authors and as infraspecific taxa by others. Some of them, for example, E. pulchellum var. praecox, seem to be ecology-dependent and occur throughout the range of this species in especially dry environments where plants develop morphotypes with closely julaceous foliage due to strongly appressed leaves that are shorter and more obtuse.

The North American flora, however, includes at least three other morphotypes that are beyond the variation of the species in at least the Russian territory (and apparently Eurasia as a whole). One of them is 'Eurhynchium strigosum var. scabrisetum Grout'. It has seta surface at places with scattered shallow raisings, although far from definite mammillosity. Nevertheless, nothing similar was reported from the area outside of Nova Angliae. However, due to rather inconspicuous mammillosity and the difficulty of identifying material by this character, this variety is not accepted in the modern literature.

A second variety, E. pulchellum var. robustum (Roll) Jennings, occurs in southeastern North America and differs primarily in the larger size of plants. The largest plants observed (Georgia, Harper, 2053g, MO) have stem $5 \mathrm{~cm}$ long, branches 10 $\mathrm{mm}$, stem leaves up to $1.4 \times 0.75 \mathrm{~mm}$, and branch leaves up to $1.25 \times 0.5 \mathrm{~mm}$. However, this variety is also usually not widely accepted because of the very gradual transition to the common morphotype that usually has stems $2-4 \mathrm{~cm}$, branches $3-5$ $\mathrm{mm}$, stem leaves $0.5-1.0 \times 0.4-0.7 \mathrm{~mm}$, and branch leaves $0.2-0.8 \times 0.2-0.4 \mathrm{~mm}$. Our observations confirm the indistinctiveness of this taxon, so it hardly merits formal recognition, at least until its distinctiveness will be demonstrated.

The third taxon is especially distinct and it is accepted here: Eurhynchiastrum pulchellum var. barnesii (Renauld \& Cardot) Ignatov, comb. nov. - Eurhynchium strigosum var. barnesii Renauld \& Cardot, Revue Bryologique 15: 72. 1888.

This variety occurs in the mountains of western North America (Montana, British Columbia, Alberta). The largest specimen seen by us has stems to $8 \mathrm{~cm}$, branches to $16 \mathrm{~mm}$, stem leaves up 
to $2.6 \times 1.8 \mathrm{~mm}$ and branch leaves $1.5 \times 0.75 \mathrm{~mm}$. Branch leaves of this size become longitudinally plicate. In addition to morphology, its distribution also supports this separation. It occurs in the area where many North American endemic and subendemic species of Brachytheciaceae occur (Sciuro-hypnum hylotapetum (N.L. Higinb. \& B.L. Higinb.) Ignatov \& Huttunen, S. oedipodium, (Mitt.) Ignatov \& Huttunen, Brachytheciastrum leibergii(Grout) Ignatov \& Huttunen, Kindbergia oregana (Sull.) Ochyra, Homalothecium nevadense(Lesq.) Renauld \& Cardot, etc.). Comparison of ITS, however, does not support a strong distinction from other populations of the species, although this conclusion is a preliminary one. It is likely that further studies of ITS haplotype distribution may show local differentiation and paths of migration, but the reproductive isolation of them seems needs further studies.

11. Sciuro-hypnum delicatulum (Flowers) Ignatov, comb. nov. (basionum: Brachythecium delicatulum Flowers, Bryologist 76: 287. 1973). This peculiar moss is still known only from the type locality in Utah (Flowers, 1973). It is apparently not allied to any group of Brachythecium, but most likely related to Scuiro-hypnum plumosum, thus the combination is suggested to consider it within Scuiro-hypnum.

\section{ACKNOWLEDGEMENTS}

The first author thank R.H. Zander and W.R. Buck for arranging his visit to MO and NYBG, curators of B, FI, DUKE, CANM, LE, VLA, UBCN, for loan of material, L. Martins for important information on specimens in B, B.Allen for discussion of difficult specimens, W.Weber for valuable information on B. brandegei, V. A. Bakalin, S.K. Kazanovsky and E.A. Ivanova for help in expeditions, R. Ochyra for translation Latin diagnoses, Terry McIntosh for English revision of the early version of the manuscript, L.Hedenäs for numerous commets and suggestions, and E.A.Ignatova for illustrations of plants. The work was partly supported by RFBR 07-04-00013, 0904-01324; and Scientific School Program НШ1275.2008.4.

\section{LITERATURE CITED}

ANDERSON, L. E., H. A. CRUM \& W. R. BUCK 1990. List of the Mosses of North America North of Mexico. - Bryologist 93(4): 448-499.
BUCK, W. R. 1999. Pleurocarpous mosses of the West Indies. - Mem. New York Bot. Garden 82: 400 pp.

CRUM, H. A. \& L. E. ANDERSON 1981. Mosses of eastern North America, Vols. 1-2. - Columbia University Press, New York. 1328 pp.

CZERNYADJEVA, I.V. 2005. A check-list of the mosses of Kamchatka Peninsula (Far East) - Arctoa 14: 13-34.

FEDOSOV, V.E. \& E.A. IGNATOVA 2008. The genus Bryoerythrophyllum (Pottiaceae, Bryophyta) in Russia. - Arctoa 17 : 19-38.

FLOWERS, S. 1973. Mosses of Utah new to science. - Bryologist 76: 286-292.

FRITSCH, R. 1991. Index to bryophyte chromosome counts. - Bryoph. Bibl. 40: 1-352.

GARDINER, A., M. IGNATOV, S. HUTTUNEN \& A. TROITSKY 2005. On resurrection of the families Pseudoleskeaceae Schimp. and Pylaisiaceae Schimp. (Musci, Hypnales). - Taxon 54: 651-663.

GOLOBOFF, P. A. 1994. NONA: A Tree Searching Program. - Program and documentation. Argentina, Tucumán, published by the author.

GORYUNOV, D.V., E.A. IGNATOVA, M.S. IGNATOV, I.A. MILYUTINA \& A.V. TROITSKY 2007. Support from DNA data for a narrow species concept in Schistidium (Grimmiaceae, Musci). - J. Bryol. 29: 98-103.

GROUT, A. J. 1897. A revision of the North American Isotheciaceae and Brachythecia. - Mem. Torr. Bot. Club 6: $131-210$.

GROUT, A. 1928. Moss flora of North America North of Mexico. Vol. III. Pt. I. - New York City, U.S.A.: 1-62.

HALL, T.A. 1999. BioEdit: a user-friendly biological sequence alignment editor and analysis program for Windows 95/98/NT. Nucl. Acids. Symp. Ser. 41: 95-98.

HEDENÄS, L. 1995. On the identity of Brachythecium campestre (C. Müll.) B., S. \& G., in Sweden, Norway and Finland. - Lindbergia 20: 94-101.

HEDENÄS, L. 1998. An overview of the Drepanocladus sendtneri complex. - J. Bryol. 20: 83-102.

HUTTUNEN, S., A. GARDINER \& M. S. IGNATOV 2007. Additional comments on the phylogeny of the Brachytheciaceae (Bryophyta). - In: Newton, A.E. \& R. Tangney (eds.) Pleurocarpous mosses: systematics and evolution. CRC Press, Boca Raton-London-New York (Systematic Association Special Volume 71): 117-143.

HUTTUNEN, S. \& M. S. IGNATOV 2004. Phylogetic analysis of Brachytheciaceae (Bryophyta) based on morphology, and sequence level data. - Cladistics 20: 151-183.

IGNATOV, M. S. 1998. Bryophyte flora of Altai Mountains. VIII. Brachytheciaceae. - Arctoa 7: 85-152.

IGNATOV, M. S. \& O. M. AFONINA (eds.) 1992. Checklist of mosses of the former USSR. - Arctoa 1: 1-85.

IGNATOV M.S., AFONINA O.M., IGNATOVA E.A., A. ABOLINA, T.V. AKATOVA, E. Z. BAISHEVA, L.V. BARDUNOV, E.A. BARYAKINA, O.A. BELKINA, A.G. BEZGODOV, M.A.BOYCHUK, V.YA. CHERDANTSEVA, I.V. CZERNYADJEVA, G.YA. DOROSHINA, A.P. DY- 
ACHENKO, V.E. FEDOSOV, I.L. GOLDBERG, E.I. IVANOVA, I. JUKONIENE, L. KANNUKENE, S.G. KAZANOVSKY, Z.KH. KHARZINOV, L.E. KURBATOVA, A.I.MAKSIMOV, U.K. MAMATKULOV, V. A. MANAKYAN, O.M. MASLOVSKY, M.G. NAPREENKO, T. N. OTNYUKOVA, L.YA. PARTYKA, O.YU. PISARENKO, N.N. POPOVA, G.F. RYKOVSKY, D.YA. TUBANOVA, G.V. ZHELEZNOVA, V.I. ZOLOTOV 2006 [2007]. Check-list of mosses of East Europe and North Asia. - Arctoa 15: 1-130.

IGNATOV, M.S. \& S. HUTTUNEN 2002. Brachytheciaceae (Bryophyta) - a family of sibling genera. - Arctoa $\mathbf{1 1}$ : 245-296.

IGNATOV, M. S. \& E. A. IGNATOVA 2003 [2004]. Brachythecium buchananii (Brachytheciaceae, Musci) - a new species for Uzbekistan. - Arctoa 12: 113-114.

IGNATOV, M.S. \& I.A.MILYUTINA 2007. On Sciuro-hypnum oedipodium and $S$. curtum (Brachytheciaceae, Bryophyta). - Arctoa 16: 47-61.

IGNATOV, M. S., I. A. MILYUTINA \& S. HUTTUNEN 2006. On two East Asian species of Brachythecium (Brachytheciaceae, Musci). - J. Hattori Bot. Lab. 100: 191-199.

IGNATOV, M. S., B. C. TAN, Z. IWATSUKI \& E. A. IGNATOVA. 2000. Moss flora of the Upper Bureya River (Russian Far East). - J. Hattori Bot. Lab. 88: 147-178.

IGNATOVA, E.A. \& V.E. FEDOSOV 2008. Species of Dicranum (Dicranaceae, Bryophyta) with fragile leaves in Russia. - Arctoa 17: 63-83.

IRELAND, R. R., G. R. BRASSARD, W. B. SCHOFIELD \& D. H. VITT 1987. Check-list of the mosses of Canada. II. Lindbergia 13: 1-62.

[KRIVOSHAPKIN, K.K., M. S. IGNATOV \& E.I. IVANOVA] КРИВОШАПКИН, К. К., М. С. ИГНАТОВ, Е.И. ИВАНОВА 2001. К флоре листостебельных мхов Национального природного парка “Ленские столбы” (устье p. Лабыйа). - [On moss flora of National Nature Park "Lenskie Stolby" (Labyja Creek mouth)] В кн.: Наичинальныци природный парк “Ленские Столбы”: геология, почвы, растительность, животный мир, охрана и использование. Якутск, НПП “Ленские Стлобы” [In: Nationalnyj Prirodny Park "Lenskie Stolby": geologiya, pochvy, rastitelnost, zhivotny mir, ochrana i ispolzovanie. Yakutsk, NPP “Lenskie Stolby” \& al.]: 71-81.

LAWTON, E. 1971. Moss Flora of the Pacific Northwest. Nichinan, Hattori Bot. Lab., xiii +362 pp. 195 pl.
[LAZARENKO, A. S., E. I. VYSOTSKAYA \& E. N. LESNҮАК] ЛАЗАРЕНКО А.С., Е.И. ВЫСОЦКАЯ, Е.Н. ЛЕСНЯК 1971. Атлас хромосом лиственных мхов CCCP. - [Atlas of chromosomes of mosses of the USSR] Киев, изд. АН УССР [Kiev, Izd. Akad. Nauk Ukrain. SSR], $142 \mathrm{pp}$.

LIMPRICHT, K. G. 1896. Die Laubmoose. - In: Rabenhorst, L. Kryptogamen-flora von Duetschland, Oesterreich und der Scheiz. Bd. 3. 1-448.

MACOUN, J. 1892. Catalogue of Canadian Plants, Part VI, Musci. - Montreal: William Foster Brown \& Co. v+ $295 \mathrm{pp}$.

McFARLAND, K. D. 1988. Revision of Brachythecium (Musci) for Mexico, Central America, South America, Antarctica and circum-Subantarctic islands. $-P h$. D. dissertation, Univ. Tennessee. xii $+537 \mathrm{pp}$.

NISHIMURA, N. \& M. HIGUCHI 1993. Checklist of mosses of Pakistan. - Crypt. Flora of Pakistan. Tokyo, National Science Museum \& Islamabad, Pakistan Museum of Natural History 2: 275--299

NIXON, K.C. 1999a. Winclada (BETA) ver. 0.9.9. available at http://www.cladistics.com/about_winc.html.

NIXON, K.C. 1999b. The parsimony ratchet, a new method for rapid parsimony analysis. - Cladistics 15: 407-414.

NYHOLM, E. 1965. Illustrated Moss Flora of Fennoscandia. II. Musci. - Lund.5: 407-647.

O'SHEA, B. J. 2006. Checklist of the mosses of sub-Saharan Africa (version 5, 12/06). - Tropical Bryology Research Reports: 6: 1-252.

PODPERA, J. 1954. Conspectus Muscorum Europaeorum. Praha, Nakladatelstvi Cesk. Akad. Ved., 699 pp.

ROBINSON, H. 1962. Generic revisions of North American Brachytheciaceae. - Bryologist 65(2): 73-146.

ROBINSON, H. \& M.S. IGNATOV 1997. Brachythecium laetum B.S.G. the correct name for the species commonly known as Brachythecium oxycladon. - Bryologist 100: 359-361.

TAKAKI, N. 1955. Researches on the Brachytheciaceae of Japan and its adjacent areas II. - J. Hattori Bot. Lab. 15: $1-69$.

WIGH, K. 1975. Scandinavian species of the genus Brachythecium (Bryophyta). I. Modification and biometric study in the B. rutabulum-B. rivulare complex. - Bot. Notiser 128(4): 463-475. 